\title{
Special National Investigative Commissions: Essential Powers and Procedures (Some Lessons from the Pearl Harbor, Warren Commission, and 9/11 Commission Investigations)
}

Lance Cole

Ixc24@psu.edu

Follow this and additional works at: https://ideas.dickinsonlaw.psu.edu/fac-works

\section{Recommended Citation}

Lance Cole, Special National Investigative Commissions: Essential Powers and Procedures (Some Lessons from the Pearl Harbor, Warren Commission, and 9/11 Commission Investigations), 41 McGeorge L. Rev. 1 (2009). 


\section{Special National Investigative Commissions: Essential Powers and Procedures (Some Lessons from the Pearl Harbor, Warren Commission, and 9/11 Commission Investigations)}

Lance Cole*

TABLE OF CONTENTS

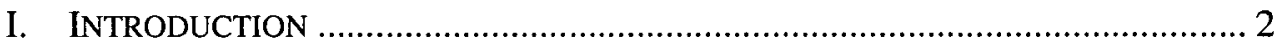

II. SPECIAl NATIONAL InVESTIGATIVE COMMISSIONS: HiSTORY AND CONTEXT

III. INVESTIGATIVE ACTIVITIES OF THE ROBERTS COMMISSION, THE

WARREN COMMISSION, AND THE 9/11 COMMISSION ................................. 9

A. The Roberts Commission and Pearl Harbor .......................................... 9

B. The Warren Commission and the John F. Kennedy Assassination ......... 14

C. The 9/11 Commission and the 9/11 Terrorist Attacks ........................... 26

IV. RECOMMENDED PRACTICES AND PROCEDURES .................................... 36

A. Commission Members: Roles, Time Commitments, and Conflicts

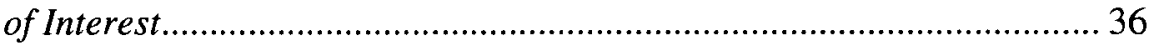

B. Commission Staffing and Investigative Resources .............................. 40

C. Commission Funding, Timetables, and Deadlines ............................ 44

D. Subpoena Power-Use and Enforcement.......................................... 46

E. Witness Testimony-Essential Powers and Procedures......................... 54

F. Transparency and Public Access .................................................... 59

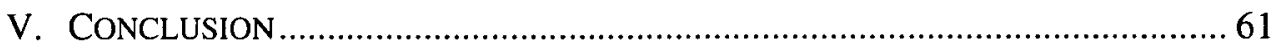

Any document that has to do with this investigation cannot be beyond our reach, [9/11 Commission Chairman Thomas H.] Kean said on Friday in his first explicit public warning to the White House that it risked a subpoena and a politically damaging courtroom showdown with the commission over access to the documents, including Oval Office intelligence reports that reached President Bush's desk in the weeks before the Sept. 11 attacks.

* Professor of Law, Penn State Dickinson School of Law. The author served as a consultant to the National Commission on Terrorist Attacks upon the United States ("the 9/11 Commission"). The views expressed in this Article are solely those of the author and should not be attributed to the $9 / 11$ Commission, its members, or its staff. 
"I will not stand for it," Mr. Kean said in the interview in his offices here at Drew University, where he has been president since 1990.

"That means that we will use every tool at our command to get hold of every document."

Philip Shenon,

9/11 Commission Could Subpoena Oval Office Files, N.Y. TIMES, Oct. 26, 2003.

\section{INTRODUCTION}

The three most traumatic events in recent American history are not difficult to identify. The September 11, 2001, terrorist attacks, the assassination of President John F. Kennedy, and the Japanese attack on Pearl Harbor all shook American society to its very core and seared our national psyche in a way that other historical events, even wars and natural disasters, have not.' The reason for the extraordinary impact of these three events probably lies in the immediate public perception-correct with the Pearl Harbor and 9/11 attacks, not the case with the Kennedy assassination-that America as a nation was under attack and the safety of our entire society was at risk.

The 9/11 attacks, the John F. Kennedy assassination, and Pearl Harbor share more than their exceptional importance in our national history, however. All three events were the subject of intensive investigations by specially constituted national investigative commissions-the Roberts Commission investigation of the Pearl Harbor attack, the Warren Commission investigation of the Kennedy assassination, and the $9 / 11$ Commission investigation of the $9 / 11$ terrorist attacks. In keeping with the magnitude of the events they investigated, these commissions were the subject of extraordinarily high public attention and interest. That public attention and interest did not end when those investigations were completed and the final reports of the investigative commissions were published. As discussed in more detail below, all three have been subject to continuing public interestand intense criticism - and have been, to various degrees, re-examined and, in some instances, even discredited. This Article reviews some of the history of these extraordinarily complex and controversial investigations with the goal of gleaning lessons and recommendations for the work of future special investigative commissions. Part II briefly surveys the history and varieties of special commissions and places the work of national investigative commissions in context. The relevant history of the Roberts Commission, Warren Commission, and 9/11 Commission investigations is summarized in Part III, and

1. Another way to make the same point is to observe that December 7, 1941, November 22, 1963, and September 11, 2001, are, in the words of one historian writing about Pearl Harbor, "crucial, turning-point dates which say: Hereafter, nothing is ever going to be quite the same again." BRUCE CATTON, THE WAR LORDS OF WASHINGTON 3 (Harcourt, Brace and Company 1948). 
recommendations are contained in Part IV. The Conclusion that follows Part IV acknowledges the unique and subject-matter-specific nature of special national investigative commissions and emphasizes that these recommendations are intended as starting points for discussion and analysis, not inflexible rules for application in all future cases.

\section{SPECIAL NATIONAL INVESTIGATIVE COMMISSIONS: HISTORY AND CONTEXT}

In most instances national problems and events of great national interest and concern are investigated, and then addressed legislatively, if necessary, through the congressional hearing and investigative process. Congressional hearings and investigations are typically an effective means for our elected representatives in government to address our social problems and respond to our national crises and scandals. But, as anyone who has observed a congressional investigative hearing can readily confirm, congressional investigations by their very nature have a substantial and unavoidable political component. As one historian observed:

In theory, congressional investigations proceed in an atmosphere of calm, reason, detachment, and impartiality toward their "informing function." In practice they proceed in the buffeting winds of fears and fancies, the ethnic, religious, and political pressures that mark a society at a particular time. Too often they reflect opinion rather than present information necessary for the legislative process. Too often they are clearly vulnerable to partisan exploitation. ${ }^{2}$

These inherent shortcomings in the congressional investigative process are usually not considered to be fatal flaws; some politics and partisanship are both expected and accepted as the price that must be paid to obtain a legislative solution to a problem or response to a crisis. ${ }^{3}$ There are notable exceptions to this general rule, however. Some events are too calamitous, and some problems are too important and intractable, for the public to tolerate the usual partisan political

2. H. Lew Wallace, The McCarthy Era 1954, in 5 CONGRESS INVESTIGATES: A DOCUMENTED HISTORY 1792-1974, at 3746 (Arthur M. Schlesinger, Jr. \& Roger Bruns eds. 1975).

3. The Chair and Vice Chair of the $9 / 11$ Commission commented upon the impediments to effective and timely congressional responses to national issues in the epilogue to their book about the $9 / 11$ Commission investigation:

We learned that the United States Congress needs help. Too often, Congress cannot deal with the toughest questions facing the nation. Because of the divisiveness in the country, the dizzying twenty-four-hour news cycle, the constant need to raise funds and travel back and forth to a home district, the complexity of some bills, and the pressure on members to be partisan team players, it is harder for Congress to take the time to work through issues and build consensus. So many tough issues now get foisted off on commissions.

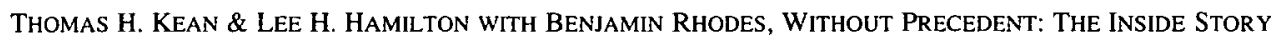
OF THE 9/11 COMMISSION 318 (2006). 
gamesmanship. ${ }^{4}$ And, from a political perspective, some situations are too politically hazardous for a president to leave the official government response entirely to the congressional investigative process. In these situations the most frequently employed solution is to create a special "blue-ribbon" commission to investigate and report on the matter. Among the many such commissions that have been created at the federal level over the past century, three stand out in terms of both the importance of the events that precipitated their creation and the extraordinarily high level of public interest in their work: the Roberts Commission investigation of the Pearl Harbor attack; the Warren Commission investigation of the assassination of President Kennedy; and the 9/11 Commission investigation of the $9 / 11$ terrorist attacks.

While these three investigations are probably the most highly publicized and controversial special investigative commissions in our national history to date, they are only a small, and in many respects unrepresentative, sample of the wide range of federal governmental commissions. Before focusing on these three exceptional examples, it is useful to place them in context by briefly surveying the larger universe of national commissions. Government special commissions come in different forms and derive their investigative mandates and powers from different sources. They have been used in this country since President George Washington sent a special commission of three members to investigate the Whiskey Rebellion in western Pennsylvania, ${ }^{5}$ and Washington's use of a special commission was probably inspired by the longstanding practice in England of employing royal commissions to address national problems. ${ }^{6}$ Since Washington's

4. A recent example of a presidential effort to characterize a national problem as so serious that the legislative response should transcend the usual congressional political gamesmanship is President Barack Obama's unusual step of publishing a newspaper op-ed piece urging Congress to act promptly to address the economic crisis in February 2009. See Barack Obama, Op-Ed., The Action Americans Need, WASH. POST, Feb. 5,2009 , at A17.

5. But see Thomas R. Wolanin, Presidential Advisory Commissions: Truman to Nixon 5 (1975).

It is often claimed that commissions were first used by President Washington and have been one of the techniques available to chief executives ever since. This view is in error. Washington's commission was a small group of men sent in 1794 to try to persuade the rebellious farmers of Pennsylvania to yield to the federal government during the Whiskey Rebellion. They were unsuccessful, and the militia were ultimately sent to end the rebellion. This commission was a group of conciliators and negotiators who, upon failing in their task, advised the President that sterner measures were needed. They were an operational group dealing directly with a crisis, and therefore more analogous to Clark Clifford's mission to Detroit during the urban riot of 1965 at the behest of President Johnson than to presidential advisory commissions as they have operated in the twentieth century.

Id. (citations omitted).

6. For a comparison of British royal commissions to U.S. blue-ribbon commissions, see KENNETH KitTs, Presidential Commissions \& National SeCurity: The Politics of DamaGe CONTRol 2-4 (2006). An early study of presidential commissions noted that the "partisan and political bias" that accompanies legislative commissions in the United States, coupled with the "separation of powers" that distinguishes the United States government from the British parliamentary structure, has prevented legislative commissions from achieving the stature and prestige accorded to British royal commissions. See CARL MARCY, PRESIDENTIAL 
presidency, the use of special commissions has waxed and waned; their use was limited in the nineteenth century and steadily increased beginning with the Administration of President Theodore Roosevelt and continuing throughout the twentieth century. Special commissions are now a fixture of our national government, and some categorization is necessary to organize the many variations that exist.

One useful means of categorizing national government commissions is to distinguish "policy" commissions from "investigative" commissions. Although the division is inexact, and some commissions straddle both sides of the division, ${ }^{7}$ it does provide a useful means of separating those commissions that are created to seek solutions to a particularly vexing public policy problem from those that are created to conduct a factual investigation of a specific event and provide a report to government and the public at large. One commentator summarized the distinctions between these categories as follows:

There are two principal types of citizens' commissions. The first is a pre-policy, advisory commission appointed to assist the executive or legislative branches of government in performing their respective responsibilities. Such commissions primarily inquire into and analyze social conditions or circumstances and render advice and recommendations for government intervention. For example, the President's Committee on Civil Rights, appointed by President Truman in 1946, was prompted by several incidents indicating that the civil rights of Black Americans were being violated throughout the country. A more recent example of such a commission is the President's Commission on Organized Crime, appointed by President Reagan in 1983. This prepolicy, advisory function is performed by Royal Commissions in England and Canada.

The second type of citizens' commission is what may be characterized as a specific event inquiry commission. Such commissions, described elsewhere as " "post mortems," are appointed in the aftermath of some public scandal, tragedy, or government misconduct. Examples of this type of commission are the Roberts Commission appointed in 1941 by President Roosevelt to inquire into the circumstances surrounding the Japanese attack on Pearl Harbor, and the Space Shuttle Challenger

Commissions 4-5 (King's Crown Press 1945).

7. For example, the report of the National Commission on Terrorist Attacks upon the United States, which is a principal focus of this Article, provided a comprehensive factual narrative of the September 11, 2001, terrorist attacks and the events that preceded those attacks. See NAT'L COMM'N ON TERRORIST ATTACKS UPON THE U.S., THE 9/11 COMMISSION REPORT 1-360 (2004), available at http://www.9-1 lcommission.gov/report/ 911 Report.pdf [hereinafter 9/11 COMMISSION REPORT]. The 9/11 Commission Report also set out a detailed and comprehensive set of policy recommendations that were aimed at preventing future terrorist attacks. See id. at $36 \mathrm{I}-428$. 
Accident Commission appointed in February 1986 by President Reagan to inquire into the space shuttle disaster that killed seven astronauts. In England, Canada, and Israel, this type of commission is called a tribunal of inquiry.

Under this nomenclature, the focus of this Article is the investigative/specific event inquiry commission, and not the pre-policy/advisory type of commission.

Another way to describe this fundamental difference among national commissions is to distinguish between "administrative" commissions, which seek to improve the administration of government, and so-called "boards of inquiry," which focus upon a particular event or perceived failure of government:

The essential distinction is that the commissions described as engaged in administrative studies are bodies seeking to improve administration as such. They may be created as a result of charges that government is expensive, its methods antiquated, or that red tape is rampant. Boards of inquiry on the other hand are bodies looking for wrongdoing. They are trying to pin guilt on someone or some organization. They are usually created as a result of an obvious failure of government or a disaster for which the public demands a complete explanation. ${ }^{9}$

Again, the focus of this Article is on "boards of inquiry," rather than the work of "administrative" commissions.

A different way to categorize national commissions is to distinguish "presidential" commissions from those created by acts of Congress. For example, the Roberts Commission and the Warren Commission were created by presidential executive orders, while the 9/11 Commission was created by a statute passed by Congress. Even this distinction is less exacting than it might first appear, however. Presidents must sign laws that Congress passes to create commissions (if one puts aside the unlikely prospect of Congress overriding a presidential veto of legislation creating a commission), and no commission requiring access to government information is likely to succeed without presidential support. By the same token, presidential commissions that seek to do more than make policy recommendations are likely to need compulsory process, which only Congress can confer upon a commission. Both the Roberts Commission and the Warren Commission sought and obtained subpoena power from Congress through joint resolutions enacted after the commissions had been formed.

8. Carl E. Singley, The MOVE Commission: The Use of Public Inquiry Commissions to Investigate Government Misconduct and Other Matters of Vital Importance, 59 TEMP. L.Q. 303, 304-05 (1986) (citations omitted).

9. MARCY, supra note 6, at 89. Marcy went on to argue that "administrative studies are most thorough and successful if undertaken under the auspices of the Executive" and that "investigations which seek to uncover wrongdoing are most appropriately undertaken under the auspices of Congress." $I d$. 
These abstract categorizations come to life when applied to actual commissions in our nation's history. The Roberts Commission, which President Roosevelt created to investigate the Pearl Harbor attack, falls clearly into the investigative commission/board of inquiry categories, and it was without question a presidential commission even though, as noted above, it obtained subpoena power through a congressional joint resolution after it was formed. ${ }^{10}$ Other Franklin Roosevelt-era commissions, such as the President's Committee on Economic Security, which laid the groundwork for the Social Security Act of 1935, and the President's Committee on Civil Service Improvement, chaired by Supreme Court Justice Stanley Reed, are classic examples of, respectively, "policy" and "administrative" commissions."

The same distinctions can be drawn between the work of the Warren Commission, a classic presidential "board of inquiry" created to perform a predominately fact-finding function, and other landmark Johnson Administration commissions. The President's Commission on Law Enforcement and the Administration of Justice, chaired by Attorney General Nicolas Katzenbach and known as the Katzenbach Commission, is a presidential commission that falls more neatly into the policy and administrative categories than the fact-finding and board of inquiry categories. President Johnson's National Advisory Commission on Civil Disorders, known as the Kerner Commission, was created to investigate urban race riots in the U.S. in the mid-1960s and is more difficult to categorize. ${ }^{12}$ This categorization difficulty is apparent from President Johnson's remarks at the signing of the Executive Order creating the Kerner Commission:

No society can tolerate massive violence, any more than a body can tolerate massive disease. And we in America shall not tolerate it.

But just saying that does not solve the problem. We need to know the answers, I think, to three basic questions about these riots:

-What happened?

-Why did it happen?

-What can be done to prevent it from happening again and again? ${ }^{13}$

10. See COMM'N APPOINTEd BY THE PRESIDENT OF THE U.S. TO INVESTIGATE AND REPORT THE FACTS RElating to the ATtaCK MADE By JAPANESE ARMEd ForCES UPON PEARL HARbor IN THE TERRITORY OF HAWAII ON DECEMBER 7, 1941, S. DOC. No. 77-159, at 1 (1942) [hereinafter ROBERTS COMMISSION REPORT].

11. See MARCY, supra note 6, at 27-28 (President's Committee on Economic Security); id. at 64-66 (President's Committee on Civil Service Improvement).

12. See generally WolANIN, supra note 5, at 102-03.

13. President's Remarks upon Signing Exec. Order Establishing the Comm'n, 3 WeEkLY CoMP. PRES. DoC. 1068 (Aug. 4, 1967). 
The three questions identified by President Johnson obviously gave the Kerner Commission a broad mandate that encompassed both fact-finding and policy recommendations. A more recent example of the same categorization difficulty is the $9 / 11$ Commission, which was responsible for both investigating the $9 / 11$ attacks and making policy recommendations to prevent future terrorist attacks.

The difficulty in categorizing independent commissions notwithstanding, the use of blue-ribbon national commissions has steadily increased in recent decades. One commentator recently sought to explain the continuing proliferation of blueribbon commissions and advisory committees in the following terms:

In the federal government, the independent advisory commission enjoys no lawmaking power. No one is obligated to pay any attention to its conclusions, and it is held to minimal, if any, standards of legal or political accountability. Yet, its proliferation throughout the twentieth century suggests that it fills a gap in the legislative's and executive's array of authorities by enabling deliberative, expert, and independent consideration of a controversial issue, whether that issue arises from a traumatic event like the $9 / 11$ attacks, or in response to more quotidian policy issues that stymie legislative and regulatory action, or symbolic issues that the President, Congress, or an Executive Branch agency wishes to acknowledge. ${ }^{14}$

An in-depth analysis of the reasons for the proliferation of independent commissions is beyond the scope of this Article and is not necessary for its main purpose, which is to analyze the powers and procedures of special investigative commissions. The three examples that are examined in more detail provide particularly fertile grounds for analysis of how commissions utilized their investigatory powers and whether they succeeded in their investigative missions. The Roberts Commission and the Warren Commission investigations were perceived as less than fully successful inquiries, and as a result, those Commissions suffered the ignominy of having their investigations reopened and reexamined by congressional panels. The 9/11 Commission, in contrast, was created in large measure because a prior congressional investigation had failed to satisfy the public demand for a complete accounting of the 9/11 attacks. All three investigations are fascinating and extraordinarily complex topics of study, as evidenced by the fact that each one has been the subject of numerous book-length studies and critiques. For that reason, the discussion that follows in this Article should not be viewed as anything approaching a comprehensive analysis of these three landmark investigative commissions, but rather as a selective examination of key topics relating to investigative procedures and practices.

14. Mark Fenster, Designing Transparency: The 9/11 Commission and Institutional Form, 65 WASH. \& LEE L. REV. 1239, 1246 (2008) (citations omitted). 


\section{INVESTIGATIVE ACTIVITIES OF THE ROBERTS COMMISSION, THE WARREN COMMISSION, AND THE 9/11 COMMISSION}

The Pearl Harbor attack was the worst military defeat in our nation's history and the only successful attack on the U.S. homeland of the twentieth century. The John F. Kennedy assassination was the only presidential assassination in the last hundred years and, according to Senator Arlen Specter, it was "the single most investigated event in world history, with the possible exception of the crucifixion of Christ." ${ }^{\text {I5 }}$ The 9/11 terrorist attacks horrified the nation and fundamentally changed the lives of all Americans. It is not especially surprising that all of these events precipitated an immediate governmental response in the form of a special blue-ribbon national investigative commission. What may be more surprising is the manner in which the investigations were conducted and the continuing controversy they have fostered.

\section{A. The Roberts Commission and Pearl Harbor}

Within days of the December 7, 1941, Japanese surprise attack on Pearl Harbor, President Roosevelt decided to create a special commission to investigate the matter. The President's decision and the membership of the Commission were announced on December 17. On December 18, the Commission's mandate was formalized with the issuance of Executive Order 8983, signed by President Roosevelt. ${ }^{16}$ The Commission was chaired by Supreme

15. ARlen SPecter with Charles Robbins, PAssion for Truth 3 (2000). As is discussed in more detail below, Senator Specter served on the staff of the Warren Commission and is credited with developing the "Single-Bullet Theory" (which he prefers to call the "Single-Bullet Conclusion" because he believes its accuracy has been established) to explain the Kennedy assassination. See id. at 1-4.

16. Exec. Order No. 8983, 6 Fed. Reg. 247 (1941).

Pursuant to the authority in me vested by the Constitution of the United States, I hereby appoint as a commission to ascertain and report the facts relating to the attack made by Japanese armed forces upon the Territory of Hawaii on December 7, 1941, the following: Associate Justice Owen J. Roberts, United States Supreme Court, Chairman; Admiral William H. Standley, United States Navy, Retired; Rear Admiral Joseph M. Reeves, United States Navy, Retired; Major General Frank R. McCoy, United States Army, Retired; Brigadier General Joseph T. McNarney, United States Army.

The purposes of the required inquiry and report are to provide bases for sound decisions whether any derelictions of duty or errors of judgment on the part of United States Army or Navy personnel contributed to such successes as were achieved by the enemy on the occasion mentioned, and if so, what these derelictions or errors were, and who were responsible therefor.

The Commission will convene at the call of its Chairman at Washington, D. C., will thereafter proceed with its professional and clerical assistants to Honolulu, Territory of Hawaii, and any other places it may deem necessary to visit for the completion of its inquiry. It will then return to Washington, D. C., and submit its report direct to the President of the United States.

The Commission is empowered to prescribe its own procedure, to employ such professional and clerical assistants as it may deem necessary, to fix the compensation and allowances of such assistants, to incur all necessary expenses for services and supplies, and to direct such travel of members and employees at public expense as it may deem necessary in the accomplishment of its mission. Each of the members of the Commission and each of its professional assistants, including 
Court Justice Owen Roberts. Two decades earlier, Roberts had served as a Department of Justice special prosecutor for the Teapot Dome scandal. More recently, as a member of the Supreme Court, Roberts had been the subject of national attention when he shifted his judicial stance on constitutional challenges to President Roosevelt's New Deal programs in the famous "switch in time that saved nine," which upheld the New Deal and averted a potential constitutional crisis over Roosevelt's "court-packing" plan. ${ }^{7}$ While Roberts's prior Teapot Dome investigative experience and position as a Supreme Court Justice made him a natural choice to head a Pearl Harbor investigative commission, the other members of the Commission all were from the military and were therefore subject to question in terms of their ability to investigate aggressively and evaluate objectively the actions of the armed services. Moreover, the Executive Order charged the Commission with investigating "whether any derelictions of duty or errors of judgment on the part of United States Army or Navy personnel contributed to such successes as were achieved by the enemy," ${ }^{18}$ an investigative mandate that arguably omitted evaluation of whether high-level civilian government officials were at fault. ${ }^{19}$ Add to these structural deficiencies, the fact that the Commission was an organ of the executive branch charged with investigating a failure of core executive branch military preparedness responsibilities, and the potential for second-guessing and loss of credibility is evident.

Immediately after its formation, the Roberts Commission promptly compounded the structural problems noted above by embarking on a series of actions that further exposed it to criticism and undermined the credibility of its investigative efforts. ${ }^{20}$ The Commission's initial interviews of high-ranking military officials in Washington were neither conducted under oath nor transcribed, procedures that were criticized during subsequent congressional inquiries. The Commission then traveled to Hawaii to conduct further factfinding on site, where witnesses were questioned under oath and on-the-record.

civilian advisers and any Army, Navy, and Marine Corps officers so employed, detailed or assigned shall receive payment of his actual and necessary expenses for transportation, and in addition and in lieu of all other allowances for expenses while absent from the place of his residence or station in connection with the business of the Commission, a per diem allowance of twenty-five dollars. All of the expenses of the Commission shall be paid by Army disbursing officers from allocations to be made to the War Department for that purpose from the Emergency Fund for the President.

All executive officers and agencies of the United States are directed to furnish the

Commission such facilities, services, and cooperation as it may request of them from time to time.

Id.

17. Barry Friedman, The History of Countermajoritarian Difficulty, Part Four: Law's Politics, 148 U. PA. L. Rev. 971, 974 (2000) (describing the historic shift by Justice Roberts from anti-New Deal to pro-New Deal voting in Supreme Court decisions).

18. Exec. Order No. 8983, 6 Fed. Reg. 247 (1941).

19. See KITTS, supra note 6, at 26-27 (discussing Admiral Standley's concerns about the breadth of the commission's investigative mandate).

20. Id. at 23-38 (describing the events summarized here in more detail). 
The Commission then returned to Washington and by the end of January presented its report, which cast blame heavily on the field military officers in Hawaii. ${ }^{21}$

A remarkable aspect of the Roberts Commission investigation was the extraordinary speed with which it completed its investigation and reported its conclusions to President Roosevelt, just over one month after it was formed. This extraordinarily expedited investigative timetable reflects the difficulty in balancing the need for a fast public report on an event of overwhelming national interest against the competing need for adequate time to conduct a thorough and complete investigation. Both the Warren Commission's investigation of the John F. Kennedy assassination and the 9/11 Commission's investigation of the 9/11 terrorist attacks, discussed below, also were greatly influenced by externally mandated completion deadlines. The issue of investigative deadlines is discussed further in Part IV below.

As noted above, the Roberts Commission has been criticized for its early investigative activities, when key officials were interviewed informally without administering oaths or making transcriptions of the interviews. The issue of what procedures for taking testimony an independent investigative commission should follow is a recurring question that commissions have faced. Under current law, even unsworn false or misleading statements by a witness can be criminally prosecuted under the federal false statements statute, ${ }^{22}$ but many witnesses may not be aware of the broad application of the federal false statements statute and may not appreciate (particularly if they are not advised by competent counsel)

21. The three key conclusions of the Roberts Commission were that:

16. The failure of the commanding general, Hawaiian Department, and the commander in chief, Pacific Fleet, to confer and cooperate with respect to the meaning of the warnings received and the measures necessary to comply with the orders given them under date of November 27, 1941, resulted largely from a sense of security due to the opinion prevalent in diplomatic, military, and naval circles, and in the public press, that any immediate attack by Japan would be in the Far East. The existence of such a view, however prevalent, did not relieve the commanders of the responsibility for the security of the Pacific Fleet and our most important outpost.

17. In the light of the warnings and directions to take appropriate action, transmitted to both commanders between November 27 and December 7 , and the obligation under the system of coordination then in effect for joint cooperative action on their part, it was a dereliction of duty on the part of each of them not to consult and confer with the other respecting the meaning and intent of the warnings, and the appropriate measures of defense required by the imminence of hostilities. The attitude of each, that he was not required to inform himself of, and his lack of interest in, the measures undertaken by the other to carry out the responsibility assigned to such other under the provisions of the plans then in effect, demonstrated on the part of each a lack of appreciation of the responsibilities vested in them and inherent in their positions as commander in chief, Pacific Fleet, and commanding general, Hawaiian Department.

18. The Japanese attack was a complete surprise to the commanders and they failed to make suitable dispositions to meet such an attack. Each failed properly to evaluate the seriousness of the situation. These errors of judgment were the effective causes for the success of the attack.

ROBERTS COMMISSION REPORT, supra note 10, at 20-21.

22. See 18 U.S.C. $\S 1001$ (2006). 
that this law is applicable even if an oath is not administered. ${ }^{23}$ Moreover, it may be viewed as coercive or intimidating for commission investigators to emphasize the false statements statute's potential application to a witness's interview or to unsworn testimony at a commission hearing. A uniform practice of swearing witnesses, on the other hand, arguably impresses upon all witnesses the importance of providing complete and truthful testimony. This issue is discussed further in Part IV below.

Similar issues surround the preparation of verbatim transcripts of all witness interviews. Using court reporters or professional stenographers for every witness statement is expensive and can be inefficient, particularly for routine background interviews. Having stenographers present also may be impractical when testimony involves classified information or sensitive, nonpublic national security matters. On the other hand, it is impossible to predict when a presumably routine witness may provide "bombshell" testimony. Probably the most notable historical example of unexpected bombshell testimony was Alexander Butterfield's interview during the Watergate congressional investigation that revealed the presence of the Nixon White House taping system. ${ }^{24}$ That event also demonstrates the problems that can arise when witness testimony is not transcribed and disputes arise as to what exactly was said by the witness. ${ }^{25}$ As a practical matter, a verbatim transcript may be the only definitive means of resolving after-the-fact disputes about exactly what a witness said in his or her testimony. This issue is also discussed further in Part IV below.

As the brief summary above establishes, the Roberts Commission investigation of the Pearl Harbor attack raises significant questions about the procedures that should be followed when conducting such an investigation. In addition, the conclusions that the Roberts Commission reached did not fare well under subsequent official and historical scrutiny. The Roberts Commission has been criticized for adopting an unduly restrictive investigative mandate; placing too much blame on the field commanders in Hawaii; failing to adequately investigate intelligence regarding secret signals that might have prompted greater readiness had it been shared with the Pearl Harbor commanders; permitting too

23. Major League Baseball player Miguel Tejada pled guilty to making false statements in a congressional investigation of steroid use in Major League Baseball. See Michael S. Schmidt, The Tumult Continues: Tejada Pleads Guilty, N.Y. TIMES, Feb. 12, 2009, at B 18. The statements that were the basis for the false statements charge against Tejada were made to congressional staff investigators during a 2005 interview in a Baltimore hotel room, not as sworn testimony during a congressional hearing. See Del Quentin Weber \& Dave Sheinin, Tejada to Plead He Lied in Inquiry, WASH. POST, Feb. 11, 2009, at E01.

24. See generally David Thelen, Conversations Between Alexander P. Butterfield and David Thelen About the Discovery of the Watergate Tapes, 75 J. AM. HIST. 1245, 1245-62 (1989) (describing how Butterfield revealed the existence of the Nixon White House taping system in an untranscribed interview conducted by Senate Watergate Committee staff members Scott Armstrong (Democratic majority staff) and Donald Sanders (Republican minority staff)).

25. Compare Donald G. Sanders, Watergate Reminiscences, 75 J. AM. HIST. 1228, 1228-33 (1989) (describing Sanders's version of the questioning of Butterfield), with Scott Armstrong, Friday the Thirteenth, 75 J. AM. HIST. 1234, 1234-44 (1989) (describing Armstrong's version of the questioning of Butterfield). 
much involvement in its work by senior civilian military officials who more properly should have been treated as within its investigative purview; and relying on investigative procedures that may have been inadequate for an investigation of such monumental importance. ${ }^{26}$ For all of these reasons, the Roberts Commission certainly cannot be judged a successful investigation. The most compelling evidence of failure is the extent to which subsequent investigations were viewed as necessary to resolve questions regarded as either left open or inadequately addressed by the Roberts Commission. The Senate Committee on Governmental Affairs report that accompanied proposed legislation to create a commission to investigate the 9/11 terrorist attacks summarized the Roberts Commission investigation and the successive investigations as follows:

\section{Pearl Harbor investigations}

In the aftermath of the December 7, 1941, attack on United States military installations at Pearl Harbor in the Hawaiian Islands, four major panels were established to conduct investigations of that event. The first of these entities was created on December 18, 1941, by E.O. 8983, "to ascertain and report the acts relating to the attack." The President's chartering order named Supreme Court Associate Justice Owen J. Roberts as chair and two retired Navy admirals and two retired Army generals as members of the panel. After interviewing 127 witnesses in Washington and Hawaii, the commission concluded its work on January 23, 1942, when it presented its report of findings-placing responsibility for the disaster with the senior Army and Navy commanders in Hawaiito the President.

The Roberts Commission was followed by three additional inquiries. On June 13, 1944, the President signed S.J. Res. 133, directing the Secretary of War and the Secretary of the Navy "to proceed forthwith with an investigation into the facts surrounding the [Pearl Harbor] catastrophe." The Army Pearl Harbor Board was in continuous session from July 24, 1944, to October 20,1944, conducting a fact-finding investigation; the board heard a total of 151 witnesses. It assessed responsibility over a wider spectrum than did the Roberts report, and placed its findings in the context of United States relations with Japan before December 7, 1941. The Navy Court of Inquiry on the Pearl Harbor attack convened on July 24, 1944 and concluded its inquiry on October 19,1944. An additional investigation ordered by the Navy was conducted during May 2, 1945, to July 12, 1945. The Navy's inquiry concentrated on the guilt or innocence of the interested parties and did

26. See Richard Ben-Veniste, The Emporer's New Clothes: Exposing the truth from WATERGATE 205-07 (2009) (describing the failings of the Roberts Commission). 


\section{9 / Special National Investigative Commissions}

not analyze as comprehensively the background of the attack or assess the responsibilities of Washington officials.

With S. Con. Res. 27 of September 11, 1945, Congress mandated the Joint Committee on the Investigation of the Pearl Harbor Attack to "make a full and complete investigation of the facts relating to the events and circumstances leading up to and following the attack made by Japanese armed forces upon Pearl Harbor." Chaired by Senator Alben W. Barkley (D-KY), the panel was composed of five Senators and five Representatives, three Democrats and two Republicans in each case. It held hearings between November 11, 1945, and May 31, 1946, and reviewed the work of the Roberts Commission and Army and Navy panels investigating the Pearl Harbor attack. The bipartisan majority report of the committee, supported by eight members of the panel, blamed the American performance at Pearl Harbor on the national defense system. ${ }^{27}$

As a final point demonstrating the poor investigative performance of the Roberts Commission, it is noteworthy that the summary above reflects that two of the three principal investigations that followed the Roberts Commission were the result of congressional action, acquiesced in by President Roosevelt. The circumstances demonstrate the lack of congressional satisfaction with the "presidential commission" investigation conducted by the Roberts Commission. A similar fate befell the other preeminent presidential commission in our nation's history, the Warren Commission; but while the Roberts Commission is generally perceived as conducting a flawed and inadequate investigation, history's verdict on the Warren Commission is less clear.

\section{B. The Warren Commission and the John F. Kennedy Assassination}

Perhaps no governmental investigation in our nation's history has been subject to more reexamination, second-guessing, and public skepticism than the Warren Commission's investigation of the assassination of President John F. Kennedy. ${ }^{28}$ The work of the Warren Commission and its conclusion that Lee Harvey Oswald acted alone in assassinating President Kennedy has been under attack for over forty years. Legions of assassination experts, conspiracy theorists, and critics of both the manner in which the investigation was conducted and the conclusions it reached have significantly eroded public confidence in the Warren

27. S. Comm. on Governmental affairs, To Establish The National Commission on TERRORIST ATTACKS UPON THE UNITED STATES, AND FOR OTHER PURPOSES, S. REP. NO. 107-150, at 5-6 (2002).

28. See SPECTER, supra note 15, at 3 ("The assassination of John Kennedy is the single most investigated event in the world in history, with the possible exception of the crucifixion of Christ. And the challenges, the skepticism, and the questions only seem to grow."). 
Commission's work. Kennedy assassination terminology such as "the SingleBullet Theory" ${ }^{29}$ and "the grassy knoll",30 have become part of our national lexicon. In 2007, writer and former Charles Manson prosecutor, Vincent Bugliosi, summarized the Kennedy assassination conspiracy theories and Warren Commission critiques as follows:

The hard-core conspiracy theorists believe not only that there was a massive conspiracy to kill the president, but that the Warren Commission learned about this conspiracy, and, as pawns of the U.S. government, entered into a new conspiracy to cover it up.

In his memoirs, Chief Justice Earl Warren, after pointing out that his commission uncovered "no facts upon which to hypothesize a conspiracy," and that separate investigations by the FBI, Central Intelligence Agency, Secret Service, and Departments of State and Defense could not find "any evidence of conspiracy," wrote, "To say now that these [agencies], as well as the Commission, suppressed, neglected to unearth, or overlooked evidence of a conspiracy would be an indictment of the entire government of the United States. It would mean the whole structure was absolutely corrupt from top to bottom, not one person of high or low rank willing to come forward to expose the villainy, in spite of the fact that the entire country bitterly mourned the death of its young President." ${ }^{\text {,31 }}$

An in-depth examination of Kennedy assassination literature is beyond the scope of this Article, but it is noteworthy that many of the most influential works focus on the investigative activities of the Warren Commission. These works share a common thesis that, rather than seeking the truth about the Kennedy assassination, the Warren Commission instead sought to establish "political truth" ${ }^{\text {"32 }}$ or "official truth" ${ }^{\text {"33 }}$ by confirming that Oswald acted alone. In so doing,

29. See, e.g., id. at 1 .

30. See, e.g., EDWARD J. EPSTEIN, INQUEST: THE WARREN COMMISSION AND THE ESTABlishmENT OF TRUTH 86-88 (1966).

31. Vincent Bugliosi, Reclaiming History: The Assassination of PREsident John F. Kennedy, at xviii, $\mathrm{xxi}(2007)$.

32. See EPSTEIN, supra note 30, at 29-62 (discussing the political truth in "Part One, "Political Truth" "). Epstein addresses why the Commission did not recognize evidence of a second assassin:

Quite clearly, a serious discussion of this problem[, evidence of a second assassin,] would in itself have undermined the dominant purpose of the Commission, namely, the settling of doubts and suspicions. Indeed, if the Commission had made it clear that very substantial evidence indicated the presence of a second assassin, it would have opened a Pandora's box of doubts and suspicions. In establishing its version of the truth, the Warren Commission acted to reassure the nation and protect the national interest.

Id. at 153-54. 


\section{9 / Special National Investigative Commissions}

the Commission ignored evidence that tended to disprove that thesis-or it may have even manipulated the evidence to support that thesis. ${ }^{34}$ Yet, despite the extraordinary efforts to disprove the Warren Commission's conclusion over the past four decades, including efforts to use new technological and forensic tools ${ }^{35}$ to shed additional light on the events of November 22, 1963, the core conclusions of the Warren Commission have never been convincingly rebutted. ${ }^{36}$ This striking disconnect between public perception and investigative results makes the Warren Commission investigation a particularly compelling study of independent commission investigative practices and procedures.

The mandate of the Warren Commission was set out in Executive Order 11130, which created the Commission "to ascertain, evaluate and report upon the facts relating to the assassination of the late President John F. Kennedy and the subsequent violent death of the man charged with the assassination," Lee Harvey Oswald. ${ }^{37}$ Although the Warren Commission was created by a presidential

33. See Gerald D. MCKNIGHT, Breach of Trust: How the WarRen COMmission FaILEd the NATION AND WHY 8-30 (2005). "That same weekend Johnson, Hoover, and Deputy Attorney General Nicholas $\mathrm{deB}$. Katzenbach settled upon the 'official truth' of the assassination, the politically accepted version fabricated for public consumption." Id. at 19.

34. In an influential early critique of the Warren Commission, Harold Weisberg states:

In its approach, operations and Report, the Commission considered one possibility alone-that Lee Harvey Oswald, without assistance, assassinated the President and killed Officer Tippit. Never has such a tremendous array of power been turned against a single man, and he was dead. Yet even without opposition the Commission failed. Not only did it fail to prove its case "beyond a reasonable doubt", the American concept, it created new doubts where none had existed.

HAROLD WEISBERG, WHITEWASH: THE REPORT ON THE WARREN REPORT 188 (1965).

35. For example, in 1978 the House Special Committee on Assassinations convened a panel of photographic science experts and used computer enhancement analysis conducted by the Los Alamos Scientific Laboratory, The Rochester Institute of Technology, the University of Southern California, and Aerospace Corp. to evaluate motion picture and photographic images that Warren Commission critics had asserted showed additional gunmen near the assassination site. See generally APPENDIX TO HEARINGS BEFORE THE H.R. SELECT COMm. ON Assassinations, Vol. VI, Photographic Evidence (Mar. 1979), available at http:/www. maryferrell.org/mffweb/archive/docset/getList.do?docSetId=1010. The panel of experts concluded that "[t]here is no definitive visible evidence of any gunmen in the streets, sidewalks, or areas adjacent to Dealey Plaza. Nor was any evidence discerned of a flash of light or puff of smoke." Id. at 109.

36. See BugliosI, supra note 31 , at xli ("But the very best testament to the validity of the Warren Commission's findings is that after an unrelenting, close to forty-five-year effort, the Commission's fiercest critics have not been able to produce any new credible evidence that would in any way justify a different conclusion.").

37. Executive Order 11,130, "Appointing a Commission to Report upon the Assassination of President John F. Kennedy," released on November 30, 1963, reads:

PURSUANT to the authority vested in me as President of the United States, I hereby appoint a

Commission to ascertain, evaluate and report upon the facts relating to the assassination of the late President John F. Kennedy and the subsequent violent death of the man charged with the assassination. The Commission shall consist of-

The Chief Justice of the United States, Chairman;

Senator Richard B. Russell;

Senator John Sherman Cooper;

Congressman Hale Boggs;

Congressman Gerald R. Ford; 
The Honorable Allen W. Dulles;

The Honorable John J. McCloy.

The purposes of the Commission are to examine the evidence developed by the Federal Bureau of Investigation and any additional evidence that may hereafter come to light or be uncovered by federal or state authorities; to make such further investigation as the Commission finds desirable; to evaluate all the facts and circumstances surrounding such assassination, including the subsequent violent death of the man charged with the assassination, and to report to me its findings and conclusions.

The Commission is empowered to prescribe its own procedures and to employ such assistants as it deems necessary.

Necessary expenses of the Commission may be paid from the "Emergency Fund for the President".

All Executive departments and agencies are directed to furnish the Commission with such facilities, services and cooperation as it may request from time to time.

/S/ LYNDON B. JOHNSON

Exec. Order No. 11,130, 28 Fed. Reg. 12,789 (Nov. 29, 1963).

38. A 1963 Joint Resolution from Congress:

Authoriz[ed] the Commission established to report upon the assassination of President John $\mathbf{F}$. Kennedy to compel the attendance and testimony of witnesses and the production of evidence.

Resolved by the Senate and House of Representatives of the United States of America in Congress assembled, That (a) for the purposes of this joint resolution, the term "Commission" means the Commission appointed by the President by Executive Order 11130, dated November 29, 1963.

(b) The Commission, or any member of the Commission when so authorized by the Commission, shall have power to issue subpenas requiring the attendance and testimony of witnesses and the production of any evidence that relates to any matter under investigation by the Commission. The Commission, or any member of the Commission or any agent or agency designated by the Commission for such purpose, may administer oaths and affirmations, examine witnesses, and receive evidence. Such attendance of witnesses and the production of such evidence may be required from any place within the United States at any designated place of hearing.

(c) In case of contumacy or refusal to obey a subpena issued to any person under subsection (b), any court of the United States within the jurisdiction of which the inquiry is carried on or within the jurisdiction of which said person guilty of contumacy or refusal to obey is found or resides or transacts business, upon application by the Commission shall have jurisdiction to issue to such person an order requiring such person to appear before the Commission, its member, agent, or agency, there to produce evidence if so ordered, or there to give testimony touching the matter under investigation or in question; and any failure to obey such order of the court may be punished by said court as a contempt thereof.

(d) Process and papers of the commission, its members, agent, or agency, may be served either upon the witness in person or by registered mail or by telegraph or by leaving a copy thereof at the residence or principal office or place of business of the person required to be served. The verified retum by the individual so serving the same, setting forth the manner of such service, shall be proof of the same, and the return post office receipt or telegraph receipt therefor when registered and mailed or telegraphed as aforesaid shall be proof of service of the same. Witnesses summoned before the Commission, its members, agent, or agency, shall be paid the same fees and mileage that are paid witnesses in the courts of the United States, and witnesses whose depositions are taken and the persons taking the same shall severally be entitled to the same fees as are paid for like services in the courts of the United States.

(e) No person shall be excused from attending and testifying or from producing books, records, correspondence, documents, or other evidence in obedience to a subpena, on the ground that the testimony or evidence required of him may tend to incriminate him or subject him to a penalty or forfeiture; but no individual shall be prosecuted or subjected to any penalty or forfeiture (except 


\section{9 / Special National Investigative Commissions}

Thus, the investigative mandate of the Warren Commission, and the investigative powers it could use to implement that mandate, were established by cooperative actions of the executive and legislative branches of government.

Before exploring further the investigative activities of the Warren Commission, two special characteristics of that commission merit brief attention. First, like the Roberts Commission, the Warren Commission was headed by a sitting member of the United State Supreme Court. While the benefits of having a Supreme Court Justice lead a special national investigative commission, in terms of bestowing credibility and negating suggestions of partisan influence, are substantial, it is not clear that service on such a commission by a sitting federal judge is advisable or even appropriate. ${ }^{39}$ Warren, for example, did not wish to serve in that capacity and only agreed to do so after being "persuaded" by President Johnson, ${ }^{40}$ and there is little doubt that Warren's responsibilities as Chief Justice detracted from his ability to devote his full time and attention to the Warren Commission. ${ }^{41}$ Despite his strong misgivings about undertaking the

demotion or removal from office) for or on account of any transaction, matter, or thing concerning which he is compelled, after having claimed his privilege against self-incrimination, to testify or produce evidence, except that such individual so testifying shall not be exempt from prosecution and punishment for perjury committed in so testifying.

(f) All process of any court to which application may be made under this Act may be served in the judicial district wherein the person required to be served resides or may be found. Approved December 13, 1963.

S.J. Res. 137, 88th Cong. (1963).

39. For an analysis of the legal and ethical issues, see Robert B. McKay, The Judiciary and Nonjudicial Activities, 35 LAW \& CONTEMP. ProBS. 9 (1970), and Solomon Slonim, Extrajudicial Activities and the Principle of the Separation of Powers, 49 CONN. B. J. 391 (1975). For a summary of extrajudicial assignments undertaken by Supreme Court Justices and federal lower court judges, see Andrew D. Herman, The WTO Dispute Settlement Review Commission: An Unwise Extension of Extrajudicial Roles, 47 HASTINGS L.J. 1635, 1643-47 (1996).

40. Herman's article provides additional perspective on Chief Justice Warren's service as chairman of the Warren Commission:

In explaining why he originally declined to serve, Chief Justice Warren stated: ["]I told [Deputy Attorney General] Katzenbach and [Solicitor General] Cox that I had more than once expressed myself to that effect for several reasons. First, it is not in the spirit of constitutional separation of powers to have a member of the Supreme Court serve on a presidential commission; second, it would distract a Justice from the work of the Court, which had a heavy docket; and, third, it was impossible to foresee what litigation such a commission might spawn, with resulting disqualification of the Justice from sitting in such cases. I then told them that, historically, the acceptance of diplomatic posts by Chief Justices Jay and Ellsworth had not contributed to the welfare of the Court, that the service of five Justices on the Hayes-Tilden Commission had demeaned it, that the appointment of Justice Roberts as chairman to investigate the Pearl Harbor disaster had served no good purpose, and that the action of Justice Robert Jackson in leaving the Court for a year to become chief prosecutor at Nuremberg after World War II had resulted in divisiveness and internal bitterness on the Court.["]

Herman, supra note 39, at 1644 n.69 (quoting Robert B. McKay, The Judiciary and Nonjudicial Activities, 35 Law \& Contemp. Probs. 9, 25 (1970) (quoting Earl Warren, The Memoirs of Earl Warren 356 (1977))).

41. Herman's article provides this historical perspective on Warren's role:

Justice Jackson's year-and-a-half absence from the Court when he was the principal prosecutor at Nuremberg was an embarrassment to the Court. Chief Justice Warren's solution in connection with 
assignment, Chief Justice Warren was unable to resist the legendary persuasive powers of President Lyndon Johnson. Arlen Specter, who played a key role in the Warren Commission's investigation as the staff member who developed the Single-Bullet Theory, has provided an insider's account of the Chief Justice's decision to head up the Commission's investigation:

Chief Justice Warren delivered our charge at an early staff meeting. All the lawyers gathered around the conference table in the commission hearing room to receive an indoctrination message from the chief justice. Earl Warren had tremendous presence, but even more so on this occasion, when he spoke of duty. His stature derived largely from his position as chief justice and the moral tone he had set for America, but he also radiated great strength as a man.

At the outset of his indoctrination talk, the chief justice explained his reasons for serving on the commission. He addressed the question that had troubled many, about the propriety of a Supreme Court justice's undertaking such an assignment. Justice Robert Jackson had drawn heavy criticism for serving as a prosecutor in the Nuremberg War Crimes Trials following World War II. Likewise, Justice Owen J. Roberts had drawn objections for his work on the commission that had investigated the Pearl Harbor attack. The Kennedy assassination probe was an especially sensitive subject, since the Supreme Court might one day have to review the prosecution then pending against Jack Ruby, or other matters arising from the assassination.

The chief justice told us he had taken on the commission job very reluctantly. "Archibald Cox, the solicitor general, came to see me and said, 'Mr. Chief Justice, I've been instructed to ask you to be chairman of the commission to investigate the assassination of President Kennedy." And Warren said, "I told Archibald Cox no. The Deputy Attorney General Nicholas Katzenbach came to talk to me. And I similarly told him no."

Attorney General Robert Kennedy did not come to talk to the chief justice. The next call came from the White House, less than two hours later. "And then President Johnson asked me to come to the Oval Office, and asked me to do it," Warren said, "and I said no." The chief justice again declined, on the ground that he should not be involved in any such task, given his responsibility to the Supreme Court. The president

the investigation of the Kennedy assassination was scarcely better when he sought to perform two crucial tasks concurrently. That Warren succeeded as well as he did is a testimonial to his capacity, not to the merit of the idea.

Herman, supra note 39, at 1644 n.69 (quoting Robert B. McKay, The Judiciary and Nonjudicial Activities, 35 LAW \& CONTEMP. PROBS. 9, 25 (1970)). 
persisted. He told Chief Justice Warren that only he could lend the credibility the country and the world so desperately needed as the people tried to understand why their heroic young president had been slain. Conspiracy theories involving communists, the U.S.S.R., Cuba, the military-industrial complex, and even the new president were already swirling. The Kennedy assassination could lead America into a nuclear war that could kill 40 million people, the president warned. President Johnson stressed that it was crucial to have men of prestige and ability to reassure the people that the whole truth was being aired. "Then the president said to me, 'Chief Justice Warren, would you refuse to put on the uniform of your country in time of national emergency, if requested by the commander in chief?"'

"Of course not," the chief justice said. Well, the president said, that was the situation they now faced. "I could hardly refuse that," Warren told us. "So I accepted." 42

The question of whether or not a sitting Supreme Court Justice should serve on a national investigative commission is closely related to the larger question of the level of activity and commitment of available professional time that should be expected of commission members. That issue is discussed further in Part IV below.

A second noteworthy structural characteristic of the Warren Commission concerns the backgrounds of its members and staff. For better or worse, the Warren Commission was a commission of lawyers. In addition to the seven commissioners, all of whom were lawyers, the Warren Commission had a staff comprised of a General Counsel, former Solicitor General of the United States, J. Lee Rankin, and fourteen Assistant Counsels, who conducted the Commission's investigation with support from twelve additional staff members and the Federal Bureau of Investigation. The Warren Commission divided its investigative mandate into six major areas and staffed each area with a senior assistant counsel and a junior assistant counsel. ${ }^{43}$ The counsels then worked with the FBI and other federal agencies to conduct the Commission's investigation.

The Warren Commission's reliance on the FBI for investigative support, rather than employing a staff of professional investigators, has been a source of criticism and controversy almost from the outset of the Commission's work. As an early and influential Warren Commission critic noted in 1966:

The Commission conducted an independent investigation without independent investigators. The Commission found it unnecessary "to

42. SPECTER, supra note 15 , at 53-54.

43. Id. at 45-46; see also EPSTEIN, supra note 30, at 73 ("[T]he legal staff was divided into six panels of lawyers; each panel consisted of a 'senior' and 'junior' lawyer; and each panel was assigned a specific area to investigate."). 
employ investigators other than the members of the Commission's legal staff," because it felt that it could rely on the facilities and investigative reports of the FBI and other federal agencies. Although the Commission in fact relied mainly on the FBI, the investigation in theory was independent, because the legal staff "critically reassessed" the reports and work of the FBI and conducted further investigations where necessary. [Warren Commission General Counsel and former Solicitor General of the United States] J. Lee Rankin said, "Our lawyers were the only independent investigators that we needed."

Warren Commission critics have asserted that the FBI was more concerned with protecting its own reputation and that of its Director, J. Edgar Hoover, than it was with supporting the Commission's investigation. ${ }^{45}$ Perhaps the most serious questions surrounding the FBI's conduct concern the Bureau's failure to provide the Secret Service with Lee Harvey Oswald's name prior to President Kennedy's visit to Dallas, when Oswald was already under FBI surveillance, and the possibility that the FBI subsequently "covered up" information about Oswald's prior contacts with the FBI Dallas office that might have reflected poorly on the Bureau. $^{46}$ In fairness to the work of the Warren Commission, however, it should be noted that the FBI did not escape unscathed in the Commission's report.

44. EPSTEIN, supra note 30, at 89 (endnotes omitted). Epstein, like other Warren Commission critics, found fault with the Commission's reliance on the FBI for investigative support and concluded that the Commission's investigation "was by no means exhaustive or even thorough." Id. at 125. Senator Arlen Specter has acknowledged that "[t]here was a basic question about whether it was sound for the commission to farm out investigative work to the FBI, which had a conflict of interest, since it was being investigated itself." SPECTER, supra note 15, at 93. Gerald D. McKnight asserts that FBI Director J. Edgar Hoover decided immediately after the assassination that Oswald must have acted alone and then manipulated the entire FBI investigative effort to support that conclusion:

Limiting the investigation from the outset to the alleged lone assassin would have consequences: All the evidence allowed to come forward in the case-ballistics, fingerprints and palm prints, fiber analysis, and other technical data--would be slanted and misrepresented to establish that Oswald, and only Oswald, fired the shots that killed Kennedy and wounded Connally.

MCKNIGHT, supra note 33, at 15 (endnote omitted).

45. For a critical account of the Bureau's alleged failings, see MCKNIGHT, supra note 33, at 247-81 (entitling Chapter 10, "FBI Blunders and Cover-Ups in the JFK Assassination").

46. McKnight offers a notably dramatic historic comparison on this issue:

It does not require special insight to appreciate how Dallas and the nation's history would have been dramatically different if the Secret Service had had Oswald's name on its "alert list." Although no analogy is perfect, a close parallel from modern U.S. history jumps to mind: the phone call that Watergate security guard Frank Wills made when he discovered tape holding a door unlocked within the complex that housed the Democratic National Committee headquarters. That call changed American history. It precipitated a cascade of events that ended in the resignation of an American president. Had [Dallas FBI agent and Oswald case agent James P.] Hosty [Jr.] walked Oswald's file over to [Dallas Secret Service agent in charge Forrest V.] Sorrels's office, this ordinary and, considering the circumstances, reasonable and expected action would also have changed history.

Id. at 263-64. 
After laying out the details of the FBI's role in the complex chain of events that preceded the Kennedy assassination, the Report concludes:

As reflected in this testimony, the officials of the FBI believed that there was no data in its files which gave warning that Oswald was a source of danger to President Kennedy. While he had expressed hostility at times toward the State Department, the Marine Corps, and the FBI as agents of the Government, so far as the FBI knew he had not shown any potential for violence. Prior to November 22, 1963, no law enforcement agency had any information to connect Oswald with the attempted shooting of General Walker. It was against this background and consistent with the criteria followed by the FBI prior to November 22 that agents of the FBI in Dallas did not consider Oswald's presence in the Texas School Book Depository Building overlooking the motorcade route as a source of danger to the President and did not inform the Secret Service of his employment in the Depository Building.

The Commission believes, however, that the FBI took an unduly restrictive view of its responsibilities in preventive intelligence work, prior to the assassination. The Commission appreciates the large volume of cases handled by the FBI $(636,371$ investigative matters during fiscal year 1963). There were no Secret Service criteria which specifically required the referral of Oswald's case to the Secret Service; nor was there any requirement to report the names of defectors. However, there was much material in the hands of the FBI about Oswald: the knowledge of his defection, his arrogance and hostility to the United States, his proCastro tendencies, his lies when interrogated by the FBI, his trip to Mexico where he was in contact with Soviet authorities, his presence in the School Book Depository job and its location along the route of the motorcade. All this does seem to amount to enough to have induced an alert agency, such as the FBI, possessed of this information to list Oswald as a potential threat to the safety of the President. This conclusion may be tinged with hindsight, but it stated primarily to direct the thought of those responsible for the future safety of our Presidents to the need for a more imaginative and less narrow interpretation of their responsibilities.

It is the conclusion of the Commission that, even in the absence of Secret Service criteria which specifically required the referral of such a case as Oswald's to the Secret Service, a more alert and carefully considered treatment of the Oswald case by the Bureau might have brought about such a referral. ${ }^{47}$

47. Earl Warren et al., Report of the President's Comm'n on the assassination of PRESIDENT KENNEDY 443 (1964) (endnotes omitted) [hereinafter WARREN COMMISSION REPORT] (on file with 
Notwithstanding this willingness of the Warren Commission to criticize the agency that it relied upon for investigative support, it is fair to ask whether the Commission received full cooperation from the FBI in areas where the Bureau's conduct was at issue. As is further discussed below, the 9/11 Commission took a different approach, assembling its own investigative staff rather than relying on the FBI or other government investigative agencies. The recommendations in Part IV below address the issue of when and to what extent an independent investigative commission should rely on investigative support from other government agencies.

Although a detailed analysis of the Warren Commission's investigative findings is beyond the scope of this Article, it is useful to review the core findings of the Commission's report that have precipitated the criticism and skepticism that is discussed above. The following is from the "Narrative of Events" section in Chapter One, "Summary and Conclusions," of the Warren Commission Report:

The President's car which had been going north made a sharp turn toward the southwest onto Elm Street. At a speed of about 11 miles per hour, it started down the gradual descent toward a railroad overpass under which the motorcade would proceed before reaching the Stemmons Freeway. The front of the Texas School Book Depository was now on the President's right, and he waved to the crowd assembled there as he passed the building. Dealey Plaza - an open, landscaped area marking the western end of downtown Dallas - stretched out to the President's left. A Secret Service agent riding in the motorcade radioed the Trade Mart that the President would arrive in 5 minutes.

Seconds later shots resounded in rapid succession. The President's hands moved to his neck. He appeared to stiffen momentarily and lurch slightly forward in his seat. A bullet had entered the base of the back of his neck slightly to the right of the spine. It traveled downward and exited from the front of the neck, causing a nick in the left lower portion of the knot in the President's necktie. Before the shooting started, Governor Connally had been facing toward the crowd on the right. He started to turn toward the left and suddenly felt a blow on his back. The Governor had been hit by a bullet which entered at the extreme right side of his back at a point below his right armpit. The bullet traveled through his chest in a downward and forward direction, exited below his right nipple, passed through his right wrist which had been in his lap, and then caused a wound to his left thigh. The force of the bullet's impact appeared to spin the Governor to his right, and Mrs. Connally pulled him down into her lap. Another bullet then struck President Kennedy in the 
rear portion of his head, causing a massive and fatal wound. The President fell to the left into Mrs. Kennedy's lap. ${ }^{48}$

It is not an exaggeration to say that no finding or conclusion of any government study or investigation has been as controversial or subject to as much criticism as the Warren Commission's conclusion that a single bullet passed through President Kennedy's body and then caused all of Governor Connally's injuries. ${ }^{49}$ No one is more entitled to respond to this harsh assessment of the Single-Bullet Theory than the theory's originator, Senator Arlen Specter. In 1964 Specter was an assistant counsel to the Warren Commission and was the staff member who developed the Single-Bullet Theory or, as Specter prefers to call it, the "Single-Bullet Conclusion":

I had developed the Single-Bullet Theory more than thirty years earlier as a staff lawyer on the President's Commission on the Assassination of President John F. Kennedy, more commonly known as the Warren Commission. I now call it the Single-Bullet Conclusion. It began as a theory, but when a theory is established by the facts, it deserves to be called a conclusion. The conclusion is that the same bullet sliced through President John F. Kennedy's neck and then tore through Texas Governor John Connally's chest and wrist, finally lodging in the governor's thigh, as the presidential motorcade wound through downtown Dallas on November 22, 1963. The Warren Commission adopted the Single-Bullet Conclusion as its official explanation. ${ }^{50}$

Specter's spirited defense of the Single-Bullet Theory has a substantial personal dimension, because when he says "I had developed the Single-Bullet Theory," he is not exaggerating or self-aggrandizing-he was the lone staff attorney responsible for the factual investigation that yielded the Single-Bullet Theory. This aspect of the Warren Commission investigation, that a single staff member was solely responsible for what proved to be the most important investigative area within the commission's mandate, reflects the importance of establishing an adequate staff support structure at the outset of a commission's work. Recommendations for adequate staffing of commission investigations are discussed in Part IV below.

48. Id. at 3 .

49. See, e.g., MCKNIGHT, supra note 33 (demonstrating the intensity of the criticism of the Single-Bullet Theory and the failure of the passage of time to mute that criticism). In a chapter entitled "Birth of the 'SingleBullet' Fabrication," McKnight observes that, "[i]f there is a Rosetta stone for the Kennedy assassination that exposed the deception of the government's investigation into the crime, it is what in time came to be referred to as the 'single bullet' theory." Id. at 181 . McKnight then asserts that the Single-Bullet Theory "was an ad hoc invention or fabrication to meet the Commission's requirements for a lone-assassin, no-conspiracy explanation of the Kennedy assassination." $I d$.

50. SPECTER, supra note 15, at 1-2. 
Like the Roberts Commission investigation of Pearl Harbor, the Warren Commission investigation of the Kennedy assassination cannot be judged, at least if public perception and widespread acceptance of its conclusions are the applicable metrics, as a successful independent commission investigation. Although the Single-Bullet Theory has never been disproved, and no credible evidence has ever been revealed to undermine the core conclusion of the Warren Commission that Oswald acted alone, ${ }^{51}$ enormous public doubt and skepticism about the Commission's conclusions remain.

51. Like the work of the Roberts Commission discussed in Part III.A above, the Warren Commission's investigative findings were tested in a subsequent congressional investigation. From 1976 to 1979, the United States House of Representatives Select Committee on Assassinations reviewed the work of the Warren Commission in investigating the Kennedy assassination (and also investigated the assassination of Dr. Martin Luther King). In 1979 the Select Committee's Final Report concluded that acoustical evidence suggested the presence of a second gunman in the Kennedy assassination and therefore the Kennedy assassination was probably the result of a conspiracy; but, as Vincent Bugliosi has explained in his exhaustive 2007 analysis of the Kennedy assassination, the Committee's conclusion has since been refuted:

Conspiracy theorists can find little comfort in the finding of the HSCA that President Kennedy "was probably assassinated as a result of a conspiracy." Nowhere did the HSCA conclude that any of the groups frequently mentioned by the theorists, such as the CIA, FBI, Secret Service, organized crime, Cuban government, anti-Castro Cuban exiles, and so on, were involved in any conspiracy to kill the president. To the contrary, the select committee specifically concluded just the opposite, that they were "not involved." For example, the HSCA said, "Based on the Committee's entire investigation, it concluded that the Secret Service, FBI, and CIA were not involved in the assassination." The sole basis for the HSCA's conclusion that there was a conspiracy was its contested and far less-than-unanimous belief that in addition to the three shots it determined that Oswald fired from the Book Depository Building (two of which, it concluded, struck the president), there was a "high probability" that a fourth shot, which it said did not hit the president, was fired from the grassy knoll. If such were actually the case, a conclusion of conspiracy would be compelled-unless one drew the unrealistic inference that two people, acting totally independent of each other, just happened to try and kill the president at the same place and moment in time.

The basis for this fourth-shot conclusion was an acoustical analysis of a police Dictabelt recording from Dallas police headquarters containing sounds, the HSCA believed, from a police motorcycle in Dealey Plaza whose radio transmitting switch was stuck in the "on" position. HSCA acoustic experts thought the sounds heard on the tape were probably those of four gunshots. However, as is discussed in considerable depth in an endnote, this fourth-shot conclusion has been completely discredited and proved to be in error by subsequent analyses of the Dictabelt. In 1982, twelve of the most prominent experts in ballistic acoustics in the country were commissioned by the National Research Council to reexamine the Dictabelt. The panel found "conclusively" from other concurrent and identifiable background noise on the Dictabelt that the sound which the HSCA experts believed to be a fourth shot actually occurred "about one minute after the assassination," when the presidential limousine was long gone down Stemmons Freeway on its way to Parkland Memorial Hospital. ...

When one removes the Dictabelt "fourth shot" from the HSCA findings, all that is really left is the HSCA's conclusion that Oswald killed Kennedy, and the fact that the committee found no evidence of any person or group having conspired with Oswald, the identical findings of the Warren Commission.

BUGLIOSI, supra note 31 , at xxii (endnotes omitted). 
The chair and vice chair of the 9/11 Commission, Thomas Keen and Lee Hamilton, acknowledged that when they set out to investigate the 9/11 terrorist attacks, they hoped to avoid the doubts and conspiracy theories that have plagued the Warren Commission since its report was released:

History also gave us a powerful incentive to be open about what level of access - to people and government documents-we were being given. This was a lesson we could take from the Warren Commission, which had looked at the John F. Kennedy assassination. For decades, the Warren Commission's findings have been poked and prodded by conspiracy theorists, in large measure the commission is not perceived as having had full access to the most secretive materials in the government. Lee Harvey Oswald may have acted alone, but over the years people could point in different directions and say to the commission, "You didn't look at this document about U.S. policy toward Cuba; you didn't talk to so-and-so; you didn't turn over this stone." To avoid such accusations, we had to be able to stand up in front of the American people and say, "We have asked for everything that has to do with the 9/11 story, and have seen everything we asked for.",52

The extent to which Kean and Hamilton succeeded in avoiding what they perceived to be the mistakes of the Warren Commission is the subject of the next section of this Article.

\section{The 9/11 Commission and the 9/11 Terrorist Attacks}

As noted in the introduction to this section, there is no doubt that the terrorist attacks of September 11, 2001, were the most traumatic events in our nation's recent history. It is not surprising that they were the subject of a blue-ribbon commission investigation. What is surprising about the 9/11 Commission investigation is the timing and the order of events. Typically, a special investigative commission is initiated quickly, to respond to public concerns and demonstrate a serious governmental commitment to a perceived national crisis. And in most instances, as with the Roberts Commission and the Warren Commission, national investigative commissions are created at the direction of the President (albeit reluctantly in the case of President Johnson and the Warren Commission), rather than Congress, which is often hesitant to cede primary investigative authority to a commission.

The 9/11 Commission turned these typical expectations upside-down. The Bush Administration had vigorously resisted calls for an independent commission investigation after the $9 / 11$ attacks, ${ }^{53}$ and the initial investigation of

52. KEAN \& HAMILTON, supra note 3, at 16-22.

53. See id.; Philip Shenon, The Commission: The UnCensored History of the $9 / 11$ 
the 9/11 attacks was conducted as a congressional investigation-a special "Joint Inquiry" by the House and Senate intelligence committees. ${ }^{54}$ The Joint Inquiry was not a complete and comprehensive investigation of the $9 / 11$ attacks, however. The focus of the Joint Inquiry was to determining whether intelligence failures had allowed the attacks to succeed and whether Congress needed to change federal laws in response. ${ }^{55}$ In addition, because the Joint Inquiry was a congressional investigation conducted within the legislative branch, the Bush Administration relied upon constitutional separation of powers arguments to limit the Joint Inquiry's access to executive branch information. ${ }^{56}$ The Bush White House also refused to permit key Administration officials to testify in the Joint Inquiry investigation. ${ }^{57}$ For these and other reasons, the ten-month congressional

INVESTIGATION 28-31 (2008). The Bush Administration may have learned a lesson from its unsuccessful opposition to the creation of the 9/11 Commission. On February 6, 2004, at the same time the Bush White House was grappling with the 9/11 Commission's requests for information and testimony from senior government officials, President Bush signed Executive Order 13,328, which created the Commission on Intelligence Capabilities of the United States Regarding Weapons of Mass Destruction (the "WMD Commission"). Exec. Order No. 13,328, 69 Fed. Reg. 6901 (Feb. 6, 2004). The WMD Commission was very different from the $9 / 11$ Commission in a number of important respects. It was created by executive order, rather than by an act of Congress, and it was housed within the executive branch-in the Executive Office of the President-rather than in the legislative branch. $I d . \S 1$. All of its members were appointed by the President, and section 2 of the Executive Order that created the Commission stated that it was "established for the purpose of advising the President in the discharge of his constitutional authority under Article II of the Constitution to conduct foreign relations, protect national security, and command the Armed Forces of the United States, in order to ensure the most effective counterproliferation capabilities of the United States and response to the September 11,2001, terrorist attacks and the ongoing threat of terrorist activity." Id. $\$ 2$ (a). These and other provisions put the WMD Commission firmly under the control of the President. Not surprisingly, unlike the 9/11 Commission, the WMD Commission operated largely in secret and with very little transparency-and with no controversial confrontations with the Bush White House-prior to the issuance of its Final Report on March 31, 2005. See generally Commission on the Intelligence Capabilities of the United States Regarding Weapons of Mass Destruction, About the Commission, http://govinfo.library.unt.edu/wmd/about.html (last visited Sept. 14, 2009) (on file with the McGeorge Law Review).

54. S. Select Comm. on Intelligence \& H.R. Permanent Select Comm. on Intelligence, Joint INQUiRy INTO INTELligenCE COMMUNITy ACTIVITIES BEFORE AND AFTER THE TERRORIST ATtaCKS OF SEPTEMBER 11, 2001, S. ReP. No. 107-351, H.R. REP. No. $107-792$ (2002). Senator Bob Graham has described the Bush White House change in position from first opposing the Joint Inquiry investigation to supporting it at the outset of its work and has speculated about the possible reasons for that change:

I didn't know what accounted for the change in attitude. Perhaps President Bush, Vice President Cheney, and Dr. Rice felt that because our investigation was to be completely bipartisan, would take place largely behind closed doors, and would be confined to intelligence matters, it had relatively little potential to harm the administration. Perhaps they felt that agreeing to this one investigation would relieve the pressure to have an independent commission, which the administration clearly was resisting. Or the President might have been genuinely curious about what had happened, and interested in turning answers into action. Whatever the motivation, we were happy to have not only the approval but the support of the White House, and to be moving forward.

Senator Bob Graham \& JefF Nussbaum, Intelligence Matters: The CIA, the FBI, Saudi ARabia, And THE FAILURE OF AMERICA'S WAR ON TERROR 119 (2004).

55. See Fenster, supra note 14, at 1269-70 (" $[\mathrm{M}]$ embers of both parties believed early on that a congressional investigation into the intelligence failures that allowed the attacks to succeed would provide sufficient information for Congress to understand these failures and adjust federal laws accordingly.").

56. See KEAN \& HAMILTON, supra note 3, at 17.

57. Id. ("National Security Advisor Condoleezza Rice did not testify before the Joint Inquiry."). 
Joint Inquiry investigation failed to satisfy the families of $9 / 11$ victims and others who were calling for a full and complete investigation of the attacks, particularly after the Bush Administration blocked the release of some twenty-seven pages of the Joint Inquiry's final report "that related to the Saudi government and the assistance that government gave to some and possibly all of the September 11th terrorists." 58

The result of this lack of satisfaction with the Joint Inquiry investigation was a remarkable example of how continued pressure from concerned citizens can ultimately force governmental action even in the face of resistance at the highest levels:

All of these factors pointed toward the need for an independent, bipartisan commission with complete access to government documents and officials. Senator Lieberman introduced legislation on this in the spring of 2002, while the Joint Inquiry was still at work, and there was extended debate through the summer about the need for an independent commission. The chief obstacle was the White House, which argued that the congressional inquiry was continuing, and that an independent investigation would distract the government from waging the ongoing war on terrorism. At several points, it appeared that the proposal to create a 9/11 Commission was dead.

This is when the $9 / 11$ families made their voices heard. . .

Over the summer of $2002,9 / 11$ families met with members of Congress and White House officials. Senators Lieberman and McCain, and Congressmen Roemer, Shays, and Chris Smith (R-N.J.) worked hard on Capitol Hill. Meanwhile the American people showed a powerful interest in the information about the $9 / 11$ attacks coming out in the Joint Inquiry and in press reports. In September, the White House ended its opposition and announced that it would back the creation of a commission-with Press Secretary Ari Fleischer directly crediting the 9/11 families by saying, "The administration has met with some of the families of the $9 / 11$ groups, who have talked about the need for a commission to look into a host of issues, and they have made compelling arguments."

58. GRAHAM \& NUSSBAUM, supra note 54, at 215. The lack of satisfaction with the Joint Inquiry investigation stemmed at least in part from the fact that, despite the many restrictions placed upon it, the Joint Inquiry discovered and made public a number of important facts and policy issues regarding the 9/11 attacks. See generally id. at 159-77 (describing "Discoveries in San Diego" by Joint Inquiry investigators, including the fact that two of the 9/11 hijackers had been living in San Diego with an FBI informant prior to the attacks, and recounting the impact of the Joint Inquiry public staff statement revealing areas in which the Bush Administration had refused to allow the Joint Inquiry to make public certain of its investigative findings). 
On the day before Thanksgiving-November 27, 2002-before an audience that included many of the $9 / 11$ families, President Bush signed the bill creating the $9 / 11$ Commission. ${ }^{59}$

As this summary of history demonstrates, the $9 / 11$ Commission was definitely a child of the legislative branch, not an offspring commission of the executive branch like the Roberts and Warren Commissions. ${ }^{60}$ In important respects, however, the $9 / 11$ Commission was more of an orphan, left without parental support from either of the political branches of government. As a preliminary matter, the $9 / 11$ Commission was not funded adequately:

The bill was not what Daschle, McCain, and the families had wanted. It provided the commission with an insultingly small budget $-\$ 3$ million over eighteen months, compared with more than $\$ 40$ million for the federal commission that investigated the Challenger disaster. "The budget was a joke," [then-Senate Democratic Leader Tom] Daschle said. $^{61}$

Beyond the issue of funding, the legislation gave the 9/11 Commission an extraordinarily broad investigative mandate ${ }^{62}$ and an exceedingly tight timetable ${ }^{63}$

59. KEAN \& HAMILTON, supra note 3, at 17-21. See also Intelligence Authorization Act for Fiscal Year 2003, Pub. L. No. 107-306, $\S 601-611,116$ Stat. 2383, 2408-13 (2002) (creating the National Commission on Terrorist Attacks upon the United States).

60. Cf. Fenster, supra note 14, at 1272 ("By situating the Commission within the legislative branch, the Commission's creators distinguished it, at least formally, from similar independent commissions in the past, even as they cited these past commissions as historic precedents.").

61. SHENON, supra note 53, at 31 .

62. See Intelligence Authorization Act $\$ 602$.

The purposes of the Commission are to-

(1) examine and report upon the facts and causes relating to the terrorist attacks of September 11, 2001, occurring at the World Trade Center in New York, New York, in Somerset County, Pennsylvania, and at the Pentagon in Virginia;

(2) ascertain, evaluate, and report on the evidence developed by all relevant governmental agencies regarding the facts and circumstances surrounding the attacks;

(3) build upon the investigations of other entities, and avoid unnecessary duplication, by reviewing the findings, conclusions, and recommendations of-

(A) the Joint Inquiry of the Select Committee on Intelligence of the Senate and the Permanent Select Committee on Intelligence of the House of Representatives regarding the terrorist attacks of September 11,2001 . . ; and

(B) other executive branch, congressional, or independent commission investigations into the terrorist attacks of September 11,2001, other terrorist attacks, and terrorism generally;

(4) make a full and complete accounting of the circumstances surrounding the attacks, and the extent of the United States' preparedness for, and immediate response to, the attacks; and

(5) investigate and report to the President and Congress on its findings, conclusions, and recommendations for corrective measures that can be taken to prevent acts of terrorism. 
in which to fulfill that mandate. These challenges were exacerbated by the fact that the legislation placed the Commission in the legislative branch of government, ${ }^{6}$ while its investigative subject was primarily the executive branch, creating, in effect, a built-in separation of powers issue for the Commission's work. All of these factors, as well as the politically divided make-up of the Commission prescribed by the statute, weighed heavily on the minds of the chair and vice chair of the $9 / 11$ Commission as they began their work in the winter of 2002:

We were set up to fail. The thought occurred to both of us as we prepared to meet for the first time on a cold day just before the Christmas season of 2002. The full 9/11 Commission would not meet for another month; this meeting would be just the two of us.

A thicket of political controversy lay ahead. The legislation creating the commission had been signed into law by President George W. Bush, after extended wrangling between Congress and the White House through the heated and often bitter midterm elections of 2002. We were scheduled to issue our final report in May 2004, just as the presidential election would be approaching full boil.

We had an exceedingly broad mandate. The legislation creating the commission instructed us to examine

(i) intelligence agencies; (ii) law enforcement agencies; (iii) diplomacy; (iv) immigration, nonimmigrant visas, and border control; (v) the flow of assets to terrorist organizations; (vi) commercial aviation; (vii) the role of congressional oversight and resources allocation; and (viii) other areas of the public and private sectors determined relevant by the Commission for its inquiry.

In other words, our inquiry would stretch across the entire U.S. government, and even into the private sector, in an attempt to understand an event that was unprecedented in the destruction it had wrought on the American homeland, and appalling even within the catalogue of human brutality.

63. Id. $\S 610(\mathrm{~b})$.

(b) FINAL REPORT.-Not later than 18 months after the date of the enactment of this Act, the Commission shall submit to the President and Congress a final report containing such findings, conclusions, and recommendations for corrective measures as have been agreed to by a majority of Commission members.

Id.

64. See id. $\S 601$ ("There is established in the legislative branch the National Commission on Terrorist Attacks Upon the United States."). 
Both of us were aware of grumbling around Washington that the 9/11 Commission was doomed-if not designed-to fail: the commission would splinter down partisan lines; lose its credibility by leaking classified information; be denied the necessary access to do its job; or alienate the 9/11 families who had fought on behalf of its creation. Indeed, the scenarios for failure far outnumbered the chances of success. What we could not have anticipated were the remarkable people and circumstances that would coalesce within and around the 9/11 Commission over the coming twenty months to enable our success.

But on December 18, 2002, we were starting without any blueprint for how to go forward. The clock had started ticking almost a month earlier, when President Bush signed the bill creating a 9/11 Commission. So we were, in fact, already running behind. ${ }^{65}$

Beyond the lack of funding, the broad investigative mandate, and the short deadline for completion of the investigation, Kean and Hamilton also realized that "[t]he issue of subpoena power was hugely important." powers granted to the $9 / 11$ Commission and the manner in which it used those powers is one of the most important legal issues presented by the $9 / 11$ Commission investigation. The legislation that created the Commission did give it subpoena power, but the issuance of a subpoena required an affirmative vote of six of the ten commissioners, or approval by both the chair and vice chair. ${ }^{67}$ With a commission comprised of five Democrats and five Republicans, headed by a Republican chairman and a Democratic vice chairman, ${ }^{68}$ this meant that any subpoena issued would require bipartisan support. ${ }^{69}$ While requiring bipartisan support for commission action may seem desirable in the abstract, as a practical matter it posed a significant limitation ${ }^{70}$ in an investigation that depended upon obtaining information from an executive branch that was controlled by one

65. KEAN \& HAMILTON, supra note 3, at 14-16.

66. Id. at 19.

67. See Intelligence Authorization Act $\S 605$ (a)(2)(A)(i) ("A subpoena may be issued under this subsection only-(I) by the agreement of the chairman and the vice chairman; or (II) by the affirmative vote of 6 members of the Commission.").

68. See id. §603(a)(2).

69. See KEAN \& HAMILTON, supra note 3, at 19-20.

70. See Fenster, supra note 14, at 1277.

These rules were intended to have an important braking effect: the Commission could not force an executive branch agency or current or former executive branch officer to provide information without the agreement of all the commissioners nominated by one of the political parties. The power-sharing scheme would either force bipartisan agreement and compromise or render the commission completely unable to act. 
political party and that was understandably concerned about the upcoming 2004 presidential election."

The political issues raised by the statute's subpoena approval process may have had a broader effect on the Commission's work than merely requiring bipartisan support for the issuance of a particular subpoena. One of the most divisive issues that confronted the Commission at the outset of its investigation was how aggressively it should use its subpoena powers. ${ }^{22}$ Kean and Hamilton, perhaps wary of the potential political divisions that might be exacerbated by frequent votes on whether or not to issue subpoenas, chose not to use the Commission's subpoena power as a regular matter of course for the Commission's requests for documents and testimony. ${ }^{73}$ When making this decision, they rejected the views of two experienced investigators on the Commission: former Watergate prosecutor Richard Ben-Veniste and former Clinton Administration Deputy Attorney General Jamie Gorelick. ${ }^{74}$ This strategy of not utilizing the subpoena power that Congress gave the Commission arguably created problems for the Commission later, when it became apparent that some government agencies had failed to comply with less formal written requests for documents, thus requiring the use of subpoenas. ${ }^{75}$

In addition to the issues surrounding the process for issuing subpoenas, the powers granted to the $9 / 11$ Commission for enforcing subpoenas were subject to important limitations that are not readily apparent from a review of the statutory language. On its face, the $9 / 11$ Commission statute appears to include strong subpoena enforcement powers, providing for both civil contempt remedies for failure to comply with a Commission subpoena ${ }^{76}$ and criminal sanctions if a

71. See SHENON, supra note 53, at 25.

There was a real political fear of an independent commission. Rove began rewriting the strategy for Bush's 2004 reelection campaign literally the day after 9/11. He knew that Bush's reelection effort centered on his performance on terrorism; almost nothing else would matter to voters. If the commission did anything to undermine Bush's antiterrorism credentials-worst of all, if it claimed that Bush had somehow bungled intelligence in 2001 that might have prevented the attacks-his reelection might well be sunk.

Id.

72. See KEAN \& HAMILTON, supra note 3, at 63-65.

73. Id. at 64 ("We decided against an aggressive use of subpoenas for several reasons."); see also Fenster, supra note 14, at 1281 (describing the Commission's strategy of "limiting the exercise of its subpoena power and therefore avoiding direct confrontation with the Executive Branch-a strategy that would also allow it to avoid intra-commission battles over authorizing the issuance of subpoenas").

74. See KEAN \& HAMILTON, supra note 3, at 64 ("Jamie Gorelick argued that subpoenas should accompany every document request, and Richard Ben-Veniste concurred that it would not be unusual to issue blanket subpoenas in an investigation such as ours."). Kean and Hamilton reportedly rejected one candidate to serve as the Commission's general counsel, experienced federal prosecutor Carol Elder Bruce, because in an interview she told them that "the commission would be making a terrible mistake if it did not quickly issue subpoenas to the Bush administration" and that the use of subpoenas was a "'no-brainer'" for a veteran criminal investigator. SHENON, supra note 53, at 93-94.

75. See SHENON, supra note 53, at 200-07 (describing the Commission's problems obtaining requested information from the FAA and NORAD).

76. Intelligence Authorization Act for Fiscal Year 2003, Pub. L. No. 107-306, §605(a)(2)(B)(i), 116 
majority of the commissioners were to vote in favor of a criminal referral. ${ }^{77}$ These powers, however, are less efficacious than they might appear. First, and most important, the civil contempt process requires lengthy court proceedings, likely followed by an even longer appellate review process, to obtain an enforceable final order. ${ }^{78}$ Although the criminal contempt option provided under the statute might appear to provide a less time-consuming means of addressing a refusal to comply with a Commission subpoena, it likely would be ineffective in the most important cases of subpoena resistance-those involving subpoenas to obtain witness testimony or documents from the executive branch. The criminal enforcement process in the statute is not self-executing by the Commission; it requires the cooperation and assistance of a federal prosecutor to bring the matter before a Grand Jury and initiate a criminal prosecution. ${ }^{79}$ While the language of the relevant statute appears to require a U.S. Attorney to bring a criminal prosecution in such cases ${ }^{80}$ historical experience ${ }^{81}$ and applicable Department of

Stat. 2383, 2410-11 (2002).

In the case of contumacy or failure to obey a subpoena issued under subsection (a), the United States district court for the judicial district in which the subpoenaed person resides, is served, or may be found, or where the subpoena is returnable, may issue an order requiring such person to appear at any designated place to testify or to produce documentary or other evidence. Any failure to obey the order of the court may be punished by the court as a contempt of that court.

Id.

77. Id. $\S 605(\mathrm{a})(2)(\mathrm{B})(\mathrm{ii})$.

In the case of any failure of any witness to comply with any subpoena or to testify when summoned under authority of this section, the Commission may, by majority vote, certify a statement of fact constituting such failure to the appropriate United States attorney, who may bring the matter before the grand jury for its action, under the same statutory authority and procedures as if the United States attorney had received a certification under sections 102 through 104 of the Revised Statutes of the United States (2 U.S.C. $\$ \S 192-194$ ) [which makes failure to comply a misdemeanor offense punishable by up to one year in prison and a fine of up to $\$ 1,000.00$ ].

ld.

\section{Cf. KEAN \& HAMILTON, supra note 3, at 64 .}

If we had issued subpoenas, litigation could have ensued as the subpoenas were contested in the courts. After all, subpoenas are not self-enforcing. A court has to decide to issue an order to enforce one. In our case, federal agencies could have taken us to court and litigated the matter. Since we had a limited amount of time and staff, the last thing we needed was to get bogged down in a court case about whether or not we were entitled to certain documents-better to have those discussions in a cooperative negotiation.

Id.

79. See 2 U.S.C. $\S 194$ (2006) (the statute that is referenced in the $9 / 11$ legislation as providing the procedure for criminal enforcement proceedings).

80. See id. (providing that the contempt certification is presented "to the appropriate United States attorney, whose duty it shall be to bring the matter before the grand jury for its action") (emphasis added).

81. See United States v. House of Representatives, 556 F. Supp. 150 (D.D.C. 1983) (referred to as "the Burford case"). The case involved the refusal of the U.S. Attorney for the District of Columbia to initiate a criminal contempt prosecution of Environmental Protection Agency Administrator Anne M. Gorsuch after, at the direction of President Ronald Reagan, she refused to testify before a House of Representatives subcommittee. Id. at 151 . The House voted to hold her in contempt of Congress and certify her contempt to the U.S. Attorney for criminal prosecution. Id. For additional background on the Burford case, see Stanley $\mathbf{M}$. Brand \& Sean Connelly, Constitutional Confrontations: Preserving a Prompt and Orderly Means by Which Congress May Enforce Investigative Demands Against Executive Branch Officials, 36 CATH. U. L. REV. 71, 77 - 
Justice policies ${ }^{82}$ suggest that a U.S. Attorney will not do so in cases where the president directs executive branch subordinates not to comply. For these reasons, the subpoena enforcement powers contained in the 9/11 Commission legislation, in application, would not have proved effective as means of compelling timely compliance with Commission subpoenas.

One additional matter concerning the 9/11 Commission's investigative practices is worthy of special attention. The 9/11 Commission, like the Roberts Commission investigation of Pearl Harbor and the Warren Commission investigation of the Kennedy assassination, was at bottom an investigation of the conduct and performance of our national government. All three investigations involved extraordinarily calamitous events that perhaps could, or even should, have been prevented by the government agencies responsible for preventing such events. In an investigation of the government, most of the important information and many of the key witnesses will come from inside the government itself. It is likely that present and former government officials, at all levels of authority and responsibility, will provide some of the most important investigative testimony, regarding both what occurred and how well the government performed-or how it failed to perform as it should have. It is also likely that the agencies that are the subjects of investigation will have strong institutional interests in defending their performance and resisting any suggestions that they failed to perform adequately. The net result is strong institutional pressure by government agencies to defend their performance, which creates an inherent conflict of interest when representatives of those agencies participate in the investigative process. Recognition of this institutional pressure and inherent conflict of interest has important implications for an investigative commission's organization and procedures.

The most obvious "lesson learned" in this area can be taken from the Warren Commission's reliance on the FBI as its investigative organ: a commission should not rely on a government agency, the conduct of which is within the scope of a commission's investigation, for investigative support. The Warren Commission's reliance on the FBI left the Commission vulnerable to criticisms that its investigation was compromised because the FBI might have been more concerned with protecting its own interests than with supporting the

83 (1986).

82. Subsequent to the Burford case, the Department of Justice, through its Office of Legal Counsel, announced a policy of not prosecuting congressional contempt citations brought against executive branch officials who refuse to testify before Congress on the basis of instructions by the president to assert executive privilege. See Prosecution for Contempt of Congress of an Executive Branch Official Who Has Asserted a Claim of Executive Privilege, 8 Op. Office of Legal Counsel 101 (1984); Response to Congressional Requests for Information Regarding Decisions Made Under the Independent Counsel Act, $10 \mathrm{Op}$. Office of Legal Counsel 68 (1986). For additional information on congressional subpoena enforcement procedures, see Morton Rosenberg \& TOdD B. TATElman, Congressional Research SERvice, Congress's ContempT POWER: A SKETCH (2007); LOUIS Fisher, CONGRESSIONAL RESEARCH SERVICE, CONGRESSIONAL INVESTIGATIONS: SUBPOENAS AND CONTEMPT POWER (2003). 
Commission's investigation. ${ }^{83}$ The $9 / 11$ Commission sought to avoid this problem by assembling its own staff of investigators ${ }^{84}$ rather than relying on the FBI for investigative support. ${ }^{85}$

The potential problems in this area extend beyond investigative support and staff resources, however. The $9 / 11$ Commission investigation highlights another manner in which the agencies that are within a commission's investigative purview can influence the investigative process. A major issue in the $9 / 11$ Commission investigation was the presence of agency "minders," or observers, at the interviews of present and former government officials. ${ }^{86}$ The Bush White House initially took the position that an agency representative must be allowed to observe the interviews of all government witnesses, including both present and former employees." The 9/11 Commissioners objected: "We wanted our witnesses to be candid and, when appropriate, critical about their agency's performance. A minder might cause somebody to think twice before speaking candidly." ${ }^{, 88}$ Despite the obvious merits of this position, the $9 / 11$ Commission

83. See supra notes $43-46$ and accompanying text.

84. Although the 9/11 Commission did not rely on the FBI or any other government agency to provide direct investigative support, its investigation was not entirely independent and, in fact, relied very heavily on the investigations already undertaken by the $\mathrm{FBI}$ and other government agencies, including the Congressional Joint Inquiry. In particular, the $9 / 11$ Commission Report draws heavily upon and references extensively the findings of the FBI's massive "PENTTBOM" investigation, as well as the investigations of numerous other federal agencies. See generally 9/11 COMMISSION REPORT, supra note 7, at 451-66 nn.1-241. In addition, the staff of the $9 / 11$ Commission could not be described as entirely "independent" of government agencies, because a number of staff members were "detailees" from federal agencies.

85. Even this precaution was not sufficient to entirely insulate the $9 / 11$ Commission from criticism for its assessment of the FBI's role and performance. The 9/11 Commission has been criticized for succumbing to FBI Director Robert Mueller's aggressive lobbying of the Commission members to avoid recommending breaking up or dramatically reorganizing the FBI:

Mueller's lobbying campaign with the $9 / 11$ Commissioners could not have been more aggressive. He was in their faces, literally. The commissioners said later that it was a remarkable thing to have the director of the FBI announce that he was ready to open his schedule to them at a moment's notice. He would return phone calls within minutes. He would meet the commissioners whenever and wherever they wished-breakfast, lunch, dinner, at the FBI's expense, of course. If a commissioner wanted to meet with Mueller in Washington, he would volunteer to drive across town to do it.

SHENON, supra note 53 , at 365 . The criticism on this point reflects the observation that Mueller's lobbying campaign appears to have been successful:

For every insult hurled [CIA Director George] Tenet's way, there was a statement of effusive praise for FBI Director Mueller. For all of its astounding failures before $9 / 11$, for all of the evidence that things had changed little at the FBI despite Mueller's promises, the commission would recommend that the FBI stay intact.

Id. at 403 .

86. KEAN \& HAMILTON, supra note 3, at 104.

87. Id.

88. Id. An internal "Commission Sensitive" memorandum detailing 9/11 Commission staff concerns regarding "intimidation of witnesses" by executive branch "minders" at commission interviews has since been made public. Memorandum from Kevin Schneid et al. to Dan Marcus and Steve Dunne, at 1 (Oct. 2, 2003), available at http:/www.scribd.com/doc/13279605/911-Commission-Memo-Executive-Branch-MindersIntimidation-of-Witnesses [hereinafter Commission Memo] (reporting that "minders have positioned 
compromised and permitted agency minders to attend the interviews of all current government employees, but not those of former employees. ${ }^{89}$ The wisdom of this compromise is open to question, as it is current employees who are most likely to fear reprisal if they provide information that might displease their superiors and adversely affect their employment and careers.

\section{RECOMMENDED PRACTICES AND PROCEDURES}

The experiences of the Roberts Commission, the Warren Commission, and the $9 / 11$ Commission suggest some important common themes and noteworthy "lessons learned" regarding the conduct of special national investigative commissions. Although future such commissions will be as unique as the particular events and issues that precipitate their creation, some guiding principles can be identified and some essential practices and procedures can be recommended for future commissions. The following recommended practices and procedures are not intended as hard and fast rules for all commissions, but rather as starting points meriting careful consideration during the process of creating, organizing, and conducting national investigative commissions. Some of these recommended practices and procedures represent dramatic departures from past practice. Some would be expensive to implement and inconvenient to administer. And some would be strenuously opposed by "permanent" government departments and agencies. But expense, inconvenience, and institutional resistance are not sufficient reasons to compromise investigative practices and procedures when the subject of investigation is a failure of government of the magnitude of the Pearl Harbor attack, the Kennedy assassination, or the $9 / 11$ terrorist attacks. In such investigations, the public interest in full accountability of government agencies and officials is paramount, and every possible effort should be made to create a historical record that is as complete and accurate as possible.

\section{A. Commission Members: Roles, Time Commitments, and Conflicts of Interest}

An essential first step toward achieving a successful independent commission investigation is to select commissioners who are able to devote the necessary time and effort to their commission's work. National investigative commission investigations are by their very nature extraordinarily challenging and timeconsuming. They require leaders with relevant experience and as much in-depth

themselves physically and conducted themselves in a manner that we believe intimidates witnesses from giving full and candid responses to our questions").

89. Commission Memo, supra note 88, at 2. Agency "minders" were not allowed at interviews of former employees unless the former employee requested that an agency representative be present. Id. Again, it is not difficult to see how this compromise too could be subject to abuse, particularly if former employees are susceptible to agency pressure to request that an agency representative attend their interviews. 
knowledge of the matters under investigation as possible. But these requirements for sufficient time and relevant experience may conflict, as the commission candidates with the best qualifications also are likely to be those with the busiest and most demanding professional lives. A careful balance must be struck to avoid naming too many commissioners who have sterling credentials and impeccable public reputations, but who are unable to devote sufficient time to the commission's investigation. Arguably the Warren Commission failed to strike the right balance on this point and had too many members with ongoing competing responsibilities that detracted from their ability to devote substantial time to the commission investigation, most notably illustrated by Earl Warren's continued service as Chief Justice of the United States. ${ }^{90}$ Warren Commission critics have pointed to the lack of commissioner involvement in the actual investigation of the Kennedy assassination as one of the flaws of that commission's work. ${ }^{91}$ To avoid this criticism, and the potential corrosive effect on a commission's reputation, every possible effort should be made to select commissioners who do not have ongoing full-time commitments that are inconsistent with devoting the majority of their professional time to the commission's investigation. Although compromises may be necessary to obtain the services of the most able commissioners, commission candidates who cannot commit to making the commission's work their highest professional priority during the term of the commission's life probably should be rejected. At a minimum, the chair and the vice chair of the commission should be in a position to devote a substantial amount of their time to the commission's work and to appear as the "public face" of the commission.

In addition to being capable and available, it also is imperative that the members of a national investigative commission be free of any actual or perceived conflict of interest relating to the commission's work. Once again, the Warren Commission and the 9/11 Commission both provide cautionary examples

90. In addition to Warren's continued service on the Supreme Court, the seven-member Warren Commission included two U.S. Senators (John Sherman Cooper and Richard B. Russell) and two U.S Representatives (Hale Boggs and Gerald R. Ford) who continued to serve in Congress during the Commission's investigation. A Warren Commission critic noted:

[T] he attendance records of the Commission show that most of the Commissioners were present for only a minor portion of the hearings. Senator Russell, who attended the fewest, heard only about 6 per cent of the testimony; whereas Allen Dulles, who attended the largest number of hearings, heard about 71 per cent. Only three Commissioners heard more than half of the testimony, and the average Commissioner heard 45 per cent.

EPSTEIN, supra note 30 , at 110 . These statistics suggest that the Warren Commission model, with heavy membership of sitting members of Congress, is not optimal for an investigative commission, at least in terms of commissioner participation.

91. See id:; MCKNIGHT, supra note 33, at 2 ("Except for the former director of central intelligence, Allen Dulles, whom Kennedy had replaced after the Bay of Pigs debacle, all of the commissioners were burdened with heavy demands on their time.").

92. An example of the importance of the public role of the chair and vice chair of a commission is the 9/11 Commission investigation and the work of Chair Tom Kean and Vice Chair Lee Hamilton acting in unison to further that commission's objectives. See generally KEAN \& HAMILTON, supra note 3. 
of potential pitfalls. The prior service of Warren Commission member Allen Dulles as director of the Central Intelligence Agency has provided fodder for many Kennedy assassination conspiracy theorists' allegations of unexplored links between Lee Harvey Oswald and the CIA. ${ }^{93}$ The 9/11 Commission was initially derailed and valuable investigative time was lost when the first selections for its chair and vice chair, Henry Kissinger and George Mitchell, fell victim to conflict of interest concerns relating to Kissinger's consulting work and Mitchell's law firm clients. ${ }^{94}$

Kissinger and Mitchell stepped down almost immediately, but conflict of interest issues continued to bedevil the 9/11 Commission. News reports focused on allegations of conflicts of interest surrounding 9/11 Commission members with connections to the airline industry. ${ }^{95}$ Although those allegations ultimately did not have a significant impact on the public's acceptance of the $9 / 11$ Commission's report, they demonstrate how even vague and attenuated allegations of conflicts of interest can distract from and potentially undermine a commission's efforts. The backgrounds of all candidates for a national investigative commission should be carefully scrutinized for any client relationships or other prior connections that could give rise to conflict of interest allegations. If possible, commissioners should be free of business or professional relationships that could reasonably be viewed as presenting a conflict of interest that might compromise a commissioner's independence and objectivity.

Some vague and unsubstantiated conflict of interest allegations can be dismissed as simply too attenuated to present problems in the minds of reasonable observers, such as allegations based upon routine consulting or law firm client matters in which the individual commission member played no personal role. ${ }^{96}$ Other conflict of interest allegations are potentially more serious,

93. An early and influential Warren Commission critic, Harold Weisberg, provided a prescient warning (or perhaps a self-fulfilling prophesy) of the potential damage that the perceived Dulles conflict of interest could inflict on the Warren Commission:

There may also be questions asked about including anyone with any connections with any intelligence or investigative agency of the government, especially because of the possibility that had to be considered and was, that Oswald might have been a government agent. For instance, Allen Dulles, a member of the Commission, was the former head of the Central Intelligence Agency and the Commission had to consider the possibility of Oswald's having a connection with the CIA and the FBI. It concluded that he had not. But it would seem that, especially with the history of the Gary Powers U-2 mission in mind, fewer questions might now or in the future be asked about impartiality or divided loyalties had another man with a different history than Dulles been appointed to the Commission.

WEISBERG, supra note 34, at xi (emphasis added).

94. See KEAN \& HAMILTON, supra note 3, at 21-22; SHENON, supra note 53, at 12-15.

95. See, e.g., Jaime Holguin, Conflicts of Interest on September 11 Panel? 6 of 10 Panel Members Allegedly Have Ties to Airline Industry, CBS NEws, Mar. 15, 2003, http://www.cbsnews.com/stories/ 2003/03/05/eveningnews/main542868.shtml (on file with the McGeorge Law Review).

96. Even in those instances, however, it may be prudent to take precautionary measures to counter any charges of bias or conflict of interest, such as having a commissioner agree to forego any compensation derived directly or indirectly from the problem clients. In extreme cases, a commissioner might agree not to participate 
particularly if they involve direct prior involvement in matters within a commission's investigative mandate. One of the more damaging allegations brought against the 9/11 Commission illustrates the perils that are present in this area. At a public hearing of the 9/11 Commission on April 13, 2004, thenAttorney General John Ashcroft took the remarkable step of asserting that one of the members of the 9/11 Commission, former Clinton Administration Deputy Attorney General Jamie Gorelick, bore a measure of personal responsibility for shaping the policies inside the Justice Department that arguably had made it more difficult to discover and foil the $9 / 11$ plot. $^{97}$ The fact that Ashcroft was defending himself against charges that he had denied FBI requests for additional counterterrorism funding immediately prior to the $9 / 11$ attacks, ${ }^{98}$ or the fact that Ashcroft's own Justice Department had continued the policies in question, ${ }^{99}$ did little to blunt the impact of his charges against Gorelick. Whatever conclusion one reaches on the merits of the Department of Justice policy issues being debated, it is undeniable that Ashcroft's attack on Gorelick diverted attention from the 9/11 Commission's investigation of the historical events preceding 9/11 and created an unwelcome sideshow in the midst of the Commission's proceedings. ${ }^{100}$

The service of former CIA Director Allen Dulles on the Warren Commission and the service of former Deputy Attorney General Jamie Gorelick on the 9/11 Commission ${ }^{101}$ are connected by a common prudential thread. Great caution

in certain areas of a commission's investigation. This was the approach taken by the $9 / 11$ Commission in response to allegations of conflicts of interest of the Commission's executive director, Philip Zelikow, stemming from his prior work for the 2001 George W. Bush presidential transition team. Zelikow was required to agree to "recuse himself from all issues involving the transition from the Clinton to the Bush Administrations and . . . be barred from participating in any interviews of senior Bush aides, including [Condoleeza] Rice." SHENON, supra note 53, at 171. Whether or not such efforts to defuse conflict of interest allegations are ultimately effective is open to debate.

97. See BEN-VENISTE, supra note 26, at 287-88; KEAN \& HAMILTON, supra note 3, at 193-96; SHENON, supra note 53, at 325-33.

98. KEAN \& HAMILTON, supra note 3, at 194; SHENON, supra note 53, at 326-27.

99. KEAN \& HAMILTON, supra note 3, at 195.

100. See id. at 196 ("The next morning, coverage of our hearing split between the accusations regarding Gorelick and the wall, and the information released in our staff reports about the FBI."); BEN-VENISTE, supra note 26 , at 291 .

In the short term, Ashcroft's strategy proved successful, diverting attention from himself. Rather than focus on the FBI revelations of Ashcroft's tepid interest in terrorism, the lead story became Jamie's authorship of the 1995 memo and the attorney general's strident accusation. Immediately, the right-wing network of talk radio bloviators and columnists jumped on the bandwagon, broadening ongoing personal attacks against me for the Rice questioning to include Jamie Gorelick and Tim Roemer. We were treated to a front-page editorial by Rupert Murdoch, the politically conservative owner of the New York Post, who branded the commissioners as "shills."

Id.

101. In considering Jamie Gorelick's service as a member of the $9 / 11$ Commission in 2003 and 2004, it is noteworthy that her service as Deputy Attorney General in the Clinton Administration concluded in 1997, some four years prior to the $9 / 11$ terrorist attacks that were the subject of the $9 / 11$ Commission's investigation. While one might reasonably have believed that this four-year interval was sufficient to make conflict-of-interest issues regarding her prior government service unlikely to arise, the Ashcroft accusations that are described 
should be exercised when naming to an investigatory commission a former highranking government official with any potential personal connection to the matters that the commission is investigating. While an unbiased reading of history suggests that both Dulles and Gorelick made important contributions to the commissions they served, a strong case can be made that both commissions would have been better served by avoiding the controversies and criticisms that surrounded those particular commissioners.

This brief overview of issues relating to the qualifications and selection of commissioners to serve on national investigative commissions suggests a clear "bottom line" rule that should be departed from in only the most extraordinary circumstances: a national investigative commission should be comprised of members who are capable in terms of experience and qualifications, available with respect to other competing demands on their time, and free of any actual or perceived conflicts of interest that could reasonably be expected to undermine the commission's work.

\section{B. Commission Staffing and Investigative Resources}

Almost as important as the membership of a national investigative commission is the make-up and leadership of the commission's professional staff. As Philip Shenon observed in his book on the 9/11 Commission: "It is a polite fiction in Washington that the reports of blue-ribbon federal commissions are written by the commissioners themselves. In truth, most of the reports are written by a professional staff led by a full-time staff director." ${ }^{102}$ The Warren Commission provides what may be the single most important example of investigative commission staff work in our national history. ${ }^{103}$ Long before he became a United States Senator, Arlen Specter was the sole member of the Warren Commission staff with the responsibility for investigating the facts relating to President Kennedy's assassination. ${ }^{104}$ In that staff capacity Specter

above illustrate the risks that are involved any time an investigative commission member has any prior involvement in the matters a commission is charged with investigating.

102. SHENON, supra note 53 , at 38 .

103. A possible rival for the title of most important single investigative staff finding in our nation's history is the Senate Watergate Committee's discovery of the Nixon White House taping system. See supra note 24 and accompanying text (discussing the Senate Committee's questioning of Alexander Butterfield). A good case can be made that the revelation of the Nixon tapes was the most important single piece of information revealed in all of the various Watergate investigations-and perhaps the greatest single evidentiary discovery in American legal history-because it was the contents of the tapes that ultimately forced Nixon to resign the presidency. Although that discovery was made in the context of a congressional investigation, not an investigation by a national investigative commission, it nonetheless demonstrates the importance and value of investigative staff work.

104. See SPECTER, supra note 15, at 45-52 (recounting how Specter came to have sole responsibility for "Area I" of the Warren Commission investigation, which covered President Kennedy's activities on the day of the assassination); see also EPSTEIN, supra note 30, at 75 ("Instead of being handled by forty full-time lawyers, the entire task of ascertaining the basic facts of the assassination fell upon one lawyer-Arlen Specter."). Senator Specter supplements his account of his responsibility for "Area I" with that of another Warren 
developed the "Single-Bullet Theory" 105 that is generally regarded as the Rosetta stone of the Kennedy assassination ${ }^{106}$ and as such has probably been subject to more scrutiny and after-the-fact attacks than any other investigative finding in world history. ${ }^{107}$ With the benefit of hindsight, few would dispute that the Warren Commission would have been better advised to devote more staff resources to that area of its investigation, not because more staff would have led to a different conclusion, but because more staff would have lessened the vulnerability of the Commission's key finding to attacks and second-guessing based upon charges of inadequate investigation and alleged failures to reconcile competing evidence. ${ }^{108}$

Although the Warren Commission experience with the Single-Bullet Theory may be an extreme example, it illustrates dramatically the point that it is simply impossible to predict at the outset of an investigation which matters or issues will require the greatest staff investigative resources. ${ }^{109}$ The only safe and prudent approach is to do everything possible to assemble an investigative staff that is adequate in both size and expertise to fulfill the investigative mandate of the

Commission staff member, David Belin:

One of the best-kept secrets inside the Commission was that Francis W. H. Adams, one of the two lawyers assigned to Area I, performed virtually no work. He should have been asked to resign when it first became apparent that he was not going to undertake his responsibilities, but because of some mistaken fear that this might in some way embarrass the commission, Mr. Adams was kept on in name only and the entire burden of Area I fell upon Arlen Specter. Fortunately for the Commission, Arlen Specter was able to carry the entire weight of Area I on his own shoulders. Nevertheless, it is indicative of the nature of investigations by governmental Commissions that the need for a second lawyer in Area I was outweighed by a political decision. The ramifications of the fact that this decision was made by the Chief Justice of the United States are indeed chilling.

SPECTER, supra note 15, at 52 (quoting DAVID W. BELIN, NOVEMBER 22, 1963: YOU ARE THE JURY 15 (New York: Quadrangle/New York Times 1973)). Epstein's account corroborates Belin's account. See EPSTEIN, supra note 30 , at 75 . The recurring problem of national investigative commissions allowing political considerations to influence staffing and other key investigative decisions, particularly timing and funding, is discussed further infra.

105. See SPECTER, supra note 15 , at $91-98$.

106. See MCKNIGHT, supra note 33, at 181 ("If there is a Rosetta stone for the Kennedy assassination that exposed the deception of the government's investigation into the crime it is what in time came to be referred to as the "single-bullet theory."').

107. As noted above, Senator Specter calls the Kennedy assassination "the single most investigated event in world history, with the possible exception of the crucifixion of Christ," SPECTER, supra note 15, at 3, and much of the investigation that has occurred since the publication of the Warren Commission Report has revolved around efforts to prove or disprove the Single-Bullet Theory.

108. For an example, see EPSTEIN, supra note 30, at 82 (listing issues surrounding the Single-Bullet Theory that "[a]n exhaustive investigation would have tested").

109. The Senate Watergate Committee staff's discovery of the Nixon White House taping system, see supra notes $24-25$, is another example of the unpredictability of the investigative process. The Watergate Committee staff members who questioned former Nixon aide Alexander Butterfield had no idea that they were about to discover a cache of crucial evidence that soon would lead directly to the political demise of the President of the United States. As a result, they conducted a relatively casual and informal interview of Butterfield, and the session was not transcribed or recorded. All parties involved would probably be happier today if a court reporter's transcript of the interview had been prepared, and history definitely would be the richer if that had taken place. The importance of transcribing witness statements is discussed in more detail infra. 
commission. ${ }^{110}$ As described above, both the Roberts Commission investigation of Pearl Harbor and the Warren Commission investigation of the Kennedy assassination have suffered from charges that the commissions devoted insufficient investigative resources to crucial areas of their investigations. While there is no failsafe means of avoiding such criticisms, future commissions would be wise to err on the side of caution and assemble an investigative staff with ample "reserves" to pursue unanticipated investigative avenues and issues.

Quantity and depth of staff investigative resources is not the only important consideration. It also is important for an investigative commission, particularly one that is investigating a politically charged and divisive matter like the Kennedy assassination or the $9 / 11$ attacks, to assemble an investigative staff with an extraordinary breadth of experience and widely diverse backgrounds. One of the strongest recurring criticisms of the Warren Commission investigation was that it relied too heavily on the FBI for investigative support."1 conflict of interest in having the FBI conduct any investigation of its own role in the events surrounding the Kennedy assassination is only the tip of a larger potential investigative conflict-of-interest iceberg, however. The greater, systemic problem is that in any investigation of a massive failure of government, which at bottom was the issue in the Pearl Harbor, Kennedy assassination, and 9/11 investigations, a staff that is weighted too heavily with investigators who came from government may be hesitant to challenge and question the actions of their former agencies or the government generally. For this reason alone, future national investigative commissions would be well-advised to recruit a staff with a broad range of backgrounds and professional experiences to ensure a critical and independent staff perspective. Most importantly, a commission should not rely too heavily on investigative support of agencies or offices that are within the commission's investigative purview or have some actual or potential conflict of interest with respect to the commission's investigation, as was the case with the Warren Commission and the FBI. ${ }^{112}$

110. Fortunately, even high-profile, national investigative commissions usually do not have investigative mandates that are as difficult and unpredictable as those of the three commissions that are the subject of this article. See KEAN \& HAMILTON, supra note 3, at 29 ("The only real examples of commissions with mandates of the same size and import as ours were the Warren Commission, in 1963-1964, and the Roberts Commission, in 1941-1942, which investigated the attack on Pearl Harbor."). Most commissions, at least if they have members with relevant investigative experience, should be able to make reliable judgments as to the amount of investigative staff resources they can reasonably be expected to require in order to complete their tasks in a timely fashion.

111. See supra notes 43-46 and accompanying text (describing the Warren Commission's reliance on the FBI for investigative support); MCKNIGHT, supra note 33, at 89-90 (criticizing Earl Warren's "proposal that the Commission restrict itself to simply evaluating the evidence fed to it by government agencies" and noting that John McCloy "cautioned Warren about relying solely on government agencies where there was "a potential culpability,' and when those agencies' reports 'may have some self-serving aspects in them'"); id. at 106 ("The reality, of course, was that the [Warren] Commission lawyers were caught up in the FBI's covert and systematic efforts to control their investigation.").

112. Although the $9 / 11$ Commission sought to avoid this problem by assembling its own investigative staff with a wide range of experience and expertise, see KEAN \& HAMILTON, supra note 3, at 38-39, problems 
A final important consideration regarding commission staff resources is the organization of the staff and the staff's relations with the individual commission members. Both the Warren Commission ${ }^{113}$ and the $9 / 11$ Commission ${ }^{114}$ have been criticized for having staff structures that insulated the commission members from the staff. While it may well be tempting for commissioners to adopt a formal "front office" structure that interposes senior staff administrators between the commission and its investigative staff-the staff structure that was employed by both the Warren Commission and the 9/11 Commission-the costs of such a structure in terms of information sharing and collegiality arguably outweigh any administrative benefits. ${ }^{115}$ Here, the bottom line is the same as in other areas of investigative tradecraft: access to more information is almost always better than limitations on access to information. The more access the individual commission members have to the nuts and bolts of the staff's investigation, the more and better informed the commissioners are likely to be at the end of the investigative process. ${ }^{116}$ Moreover, commissioners who do not wish to be bogged down in the details of the staff's factual investigation will not be required to do so, as they always will have the authority to make their preferences known to the staff, while those who wish to get their hands dirty by digging into the factual details with the staff should be free to do so. Interposing a formal front office structure between the bulk of the staff and the commission members unavoidably interferes with information sharing. The wiser approach is to take pains to ensure that the commission's staff structure and organization will not unduly insulate commissioners from staff input and views.

still arose in this area. Most notably, Executive Director Philip Zelikow's prior ties to the Bush Administration transition team and to Bush National Security Adviser Condoleeza Rice created serious problems in the public's perception of the Commission's work. See SHENON, supra note 53, at 262-63 (recounting Tim Russert's questioning of 9/11 Commission Co-Chairs Kean and Hamilton on Meet the Press about Zelikow's role in the investigation and conflicts of interest).

113. See EPSTEIN, supra note 30, at 110-11.

114. See SHENON, supra note 53, at 69-70 (describing limitations on 9/11 Commissioners' access to staff), 84-85 (describing efforts by 9/11 Commission Executive Director Philip Zelikow to prevent commission staff members from returning telephone calls from commission members without his permission).

115. Some members of the 9/11 Commission opposed the implementation of a "front office" structure in that investigation, but their objections were overruled by Co-Chairs Kean and Hamilton. See KEAN \& HAMILTON, supra note 3, at 37-38 (describing their decision to implement a "front-office triumvirate" of an executive director, deputy executive director, and general counsel who would manage the staff). Other commissioners feared that such a staff structure would create the same kind of information "stovepipes" that had plagued the FBI and CIA prior to $9 / 11$ and made them unable to "connect the dots" prior to the attacks, see SHENON, supra note 53, at 85 (describing concerns of Commissioner and former Senator Max Cleland), and that a front office structure would unduly concentrate control of the investigation in the executive director, see id. at 69-70 (describing concerns of Commissioner and former Watergate prosecutor Richard Ben-Veniste).

116. Cf. BEN-VENISTE, supra note 26, at 220-21 (describing objections to an attempt by $9 / 11$ Commission Executive Director Philip Zelikow to limit staff members' contacts with individual commissioners and observing that restrictions on communications among staff "teams" investigating different matters "would serve to imitate the very 'stovepiping' that had badly served the nation in pre-9/11 interrelationships among member agencies of our intelligence community"). 


\section{Commission Funding, Timetables, and Deadlines}

Thomas Kean and Lee Hamilton made the dramatic statement that the 9/11 Commission was "set up to fail" before the commission's work even began." The funding limitations and relatively short investigative timetable built into the 9/11 Commission's enabling statute ${ }^{118}$ created what Kean and Hamilton called "an impossible task"119 for the Commission. The timing issue had been exacerbated by the Commission's false start resulting from the Henry Kissinger and George Mitchell appointments and resignations. ${ }^{120}$ The Warren Commission faced similar problems arising from its tight investigative timetable, and critics of that Commission have asserted that important investigative leads were not pursued because investigative time ran out. ${ }^{121}$ The Roberts Commission was also roundly criticized for conducting much too hurried an investigation of the Pearl Harbor attacks. ${ }^{122}$

Obviously, these kinds of criticisms of an investigative commission's work should be avoided if at all possible. Whether a commission is established by executive order or by congressional legislation, ${ }^{123}$ every possible effort should be made to provide adequate funding and to set a realistic timetable. This is not to say that reasonable and well-considered limitations on funding and the permitted duration of an investigation are not necessary and desirable. Large, complex investigations have a tendency to expand beyond their original objectives, and recent history of independent counsel investigations ${ }^{124}$ suggests that both a deadline and a funding limit are essential for such investigations. What is required in this area is a careful balance between the need for adequate time and

117. KEAN \& HAMILTON, supra note 3 , at 14.

118. See supra notes 62-63 and accompanying text.

119. KEAN \& HAMILTON, supra note 3 , at 14 .

120. See supra text accompanying note 94; KEAN \& HAMILTON, supra note 3, at 21-22; SHENON, supra note 53 , at $12-15$.

121. See EPSTEIN, supra note 30, at 100 (describing "The Time-Pressure Problem" and asserting that "deadlines limited not only the quantity of the investigation but also its quality"). $C f$. MCKNIGHT, supra note 33 , at 361 ("'[S]ettling the dust' of Dallas as quickly as possible was the course the executive branch settled upon.").

122. See supra notes $20-21$ and accompanying text (discussing perceived shortcomings of the Roberts Commission investigation).

123. See supra pp. 6-7 (discussing differing methods of creating national investigative commissions).

124. The length and cost of Independent Counsel Lawrence Walsh's investigation of the Iran-Contra affair and Independent Counsel Kenneth Starr's investigation of Whitewater and the Monica Lewinsky matter were the sources of widespread criticism and public disapproval and likely were the principal reasons Congress ultimately declined to renew the Independent Counsel Act. See BEN-VENISTE, supra note 26, at 131-32.

The independent counsel law had been allowed to expire in December 1992, following the seemingly interminable investigation of the Iran-Contra scandal by retired (Republican) judge Lawrence Walsh. The tension between having a credible and impartial investigation of the nation's highest political figures independent of the Department of Justice and a prosecutor with a virtually unlimited budget focused on one subject was resolved in favor of letting the new law lapse. 
funds for a complete and thorough investigation, on the one hand, and the need for limits on costs and a timely completion of the investigation, on the other hand.

Unfortunately, not one of the three major investigations that are the subject of this Article managed to strike this balance properly. The Roberts Commission was conducted too hurriedly, and as a result it is widely perceived as a failure. The Warren Commission has suffered greatly from critics' claims that it did not devote enough time and investigative resources to the central events of the Kennedy assassination. The 9/11 Commission faced an uphill battle from the outset of its investigation, due to funding constraints and an unrealistic completion date in the original legislation. It then was forced to waste valuable time and commissioner attention to obtain additional funding and a two-month extension to complete its report. ${ }^{125}$

These three significant failures to address properly the funding and timing issues in what were arguably the three most important national investigative commissions of the last century suggest that special attention should be focused on these issues when future commissions are created. Two guiding principles can be extracted from these unfortunate past missteps. First, it is clear that when a national investigative commission is established, funding for the commission's work should be adequate at the outset to avoid the necessity for distracting and demoralizing subsequent requests for additional funds. Accepting obviously inadequate funding as a political compromise to help get a commission established, as occurred with the $9 / 11$ Commission, may appear to be a smart move at the time, but in the long run it is both unwise and extremely counterproductive. The same considerations apply to the initial timetable that is established for an investigation. While a reasonable reporting deadline is appropriate, the 9/11 Commission experience teaches that the timetable for completing the commission's work should not be unrealistically short in terms of the commission's investigative mandate. The Warren Commission experience suggests that future commissions should be wary of imposing internal deadlines that may unduly truncate staff investigations. The Roberts Commission experience shows that the consequences of a rushed investigation can be calamitous in terms of history's final assessment of a commission's work. When history will be the final judge of an investigation's merit, a little extra money and time may ultimately prove to be well-spent.

A second timing and funding lesson that can be drawn from these three commission investigations is perhaps the most difficult to apply in the real world. In all three cases that are the subject of this Article, the investigative process was trumped by political considerations. The Roberts Commission rushed to judgments in an ill-considered effort to appease an impatient president and an

125. For a description of the extraordinary efforts that were required to obtain the extension for the $9 / 11$ Commission, see KEAN \& HAMILTON, supra note 3, at 143-49. 
angry public. The Warren Commission strove mightily to act quickly to calm a nervous public. The 9/11 Commission declined to seek an extension for its investigation into a presidential election season, even though the rush to conclude before the election campaign season began in earnest compromised the time available for deliberation and final drafting of its report. Although each of these decisions is understandable, and hindsight is always more clear than foresight, all three commissions probably would have been considerably less vulnerable to subsequent attack--and perhaps would have produced superior final products-if they had simply disregarded political considerations and refused to rush their investigations. For these reasons, the most important funding and timing lesson that can be drawn from these three commissions is that future commissions should not be subject to artificial deadlines dictated by political or other considerations that are irrelevant to the commission's investigative mission.

\section{Subpoena Power-Use and Enforcement}

Once an investigative commission is constituted and staffed, it must collect information if it is to fulfill its mandate. Experience suggests that, for a commission to function effectively, it must have, and should use, subpoena power to compel the production of documents and testimony. While the Roberts Commission and the Warren Commission ${ }^{126}$ for the most part enjoyed cooperation in collecting evidence, the 9/11 Commission had a different experience. After an early - and internally controversial-decision not to use subpoena power to collect evidence, the $9 / 11$ Commission was ultimately forced to use its subpoena power to obtain necessary information from recalcitrant federal agencies. ${ }^{127}$

While it is tempting to assess the 9/11 Commission experience as simply an example of an unwise initial policy decision-and conclude that the commissioners who urged use of subpoenas at the outset of the investigation were correct ${ }^{128}$ - that assessment would gloss over the complexity of the legal

126. As discussed above, see supra notes 43-46 and accompanying text, the Warren Commission may not have actually received full and complete cooperation from the FBI respecting information in the possession of the Bureau relating to the Kennedy assassination, but the Bureau's official posture was one of cooperation and support for the Warren Commission's work.

127. See supra text accompanying notes 66-74 (describing the 9/11 Commission's initial policy decision not to use its subpoena power and its eventual resort to subpoenas to obtain information from the FAA and NORAD).

128. Commissioners Ben-Veniste and Gorelick reportedly advocated strongly in favor of such a policy. See supra note 74; KEAN \& HAMILTON, supra note 3, at 64; SHENON, supra note 53, at 93-94. Representatives of the families of the victims of the 9/11 attacks also urged Co-Chairs Kean and Hamilton to conduct an aggressive investigation, stating, "We want to see lots of subpoenas." KEAN \& HAMILTON, supra note 3, at 5455. Despite these admonitions, Kean and Hamilton, who were not lawyers and therefore may have been somewhat wary of adopting a litigation-based approach to information collection, decided to employ a strategy of seeking voluntary cooperation rather than employing a more adversarial subpoena strategy:

There was a political side as well. Subpoenas of the White House or executive branch agencies from 
issues involved. Although it is possible that a policy of uniformly issuing subpoenas and demonstrating a willingness to enforce those subpoenas by aggressively utilizing the available statutory enforcement measures ${ }^{129}$ would have avoided the problems the $9 / 11$ Commission encountered, it is not clear that this approach necessarily would have ensured compliance with the Commission's information requests. The reason for this uncertainty stems from two related practical limitations that significantly hampered the ability of the $9 / 11$ Commission to effectively use its subpoena power-the limited life of the $9 / 11$ Commission and the limited efficacy of the subpoena enforcement measures in the Commission's enabling statute.

The 9/11 Commission's relatively short lifespan made any delays spent litigating a subpoena enforcement action particularly unpalatable to the commissioners, especially Co-Chairs Kean and Hamilton. ${ }^{130}$ The short lifespan also increased the likelihood that in any subpoena confrontation a recalcitrant subpoena recipient could successfully adopt a "run out the clock" litigation strategy and simply outlast the Commission. This timing problem applied to both of the subpoena enforcement methods available to the $9 / 11$ Commission under its enabling statute. The first means of enforcing a 9/11 Commission subpoena, seeking a civil court order from a federal district court to enforce the subpoena, ${ }^{131}$ meant that enforcement of the subpoena would be subject to the scheduling

the $9 / 11$ Commission would have appeared adversarial. It was neither our charge nor our intention to be an adversary to the White House; to do so would have led half the country, and possibly several of the Republican commissioners, to question our motives. We were supposed to be independent, not necessarily confrontational. We were investigating a national catastrophe, not a White House transgression; this was $9 / 11$, not Watergate.

Id. at 64-65; see also BEN-VENISTE, supra note 26, at 223 (explaining that "it was the consensus of the others [on the Commission] that issuing subpoenas would be 'too confrontational' and 'punitive,' without first giving the agencies the opportunity to respond 'voluntarily' to our written requests"); SHENON, supra note 53, at 70-71 (describing Kean and Hamilton's initial policy decision that "[t]here would be no routine subpoenas,... [which] would be seen as too confrontational, perhaps choking off cooperation from the Bush administration from the very start of the investigation").

129. See Intelligence Authorization Act for Fiscal Year 2003, Pub. L. No. 107-306, § 605(a)(2)(B)(i), 116 Stat. 2383 (2002).

130. See KEAN \& HAMILTON, supra note 3, at 64 .

If we had issued subpoenas, litigation could have ensued as the subpoenas were contested in the courts. After all, subpoenas are not self-enforcing. A court has to decide to issue an order to enforce one. In our case, federal agencies could have taken us to court and litigated the matter. Since we had a limited amount of time and staff, the last thing we needed was to get bogged down in a court case about whether or not we were entitled to certain documents-better to have those discussions in a cooperative negotiation.

Id.

\section{See Intelligence Authorization Act $\S 605(\mathrm{a})(2)(\mathrm{B})(\mathrm{i})$.}

In the case of contumacy or failure to obey a subpoena issued under subsection (a), the United States district court for the judicial district in which the subpoenaed person resides, is served, or may be found, or where the subpoena is returnable, may issue an order requiring such person to appear at any designated place to testify or to produce documentary or other evidence. Any failure to obey the order of the court may be punished by the court as a contempt of that court. 
vagaries and unpredictable appeals process of the federal courts. ${ }^{132}$ The second enforcement method, requesting a U.S. Attorney to bring the matter before a federal grand jury for prosecution, ${ }^{133}$ also provided no assurance of a prompt resolution of a subpoena dispute. Moreover, grand jury secrecy requirements ${ }^{134}$ would have precluded the Commission and its staff counsel from participating fully in the efforts to enforce the subpoena. As a practical matter, therefore, neither of the subpoena enforcement powers granted to the 9/11 Commission were sufficient to ensure that it could obtain the information it needed within the short time frame available to it.

Even putting aside timing issues, the subpoena enforcement powers given to the 9/11 Commission, as discussed in more detail above, ${ }^{135}$ were not adequate to ensure compliance from the most important sources of information sought by the Commission-federal government agencies and offices, including the White House. Because the $9 / 11$ Commission was a legislative branch entity, ${ }^{136}$ seeking a federal court order enforcing a subpoena and seeking contempt of court sanctions if the order was not obeyed would have raised serious separation of powers issues if the party resisting the subpoena was an executive branch office or agency. ${ }^{137}$ When congressional subpoenas have been resisted by federal agencies, the federal courts have been reluctant to intervene and have preferred to push the parties toward a political compromise that avoids judicial fiat as a means of resolving the conflict. ${ }^{138}$ Although a federal district court recently upheld the

\section{See id.}

133. See id. $\S 605(\mathrm{a})(2)(\mathrm{B})(\mathrm{ii})$.

In the case of any failure of any witness to comply with any subpoena or to testify when summoned under authority of this section, the Commission may, by majority vote, certify a statement of fact constituting such failure to the appropriate United States attorney, who may bring the matter before the grand jury for its action, under the same statutory authority and procedures as if the United States attorney had received a certification under sections 102 through 104 of the Revised Statutes of the United States (2 U.S.C. 192 through 194) [which makes failure to comply a misdemeanor offense punishable by up to one year in prison and a fine of up to $\$ 1,000.00]$.

Id.

134. See FED. R. CRIM. P. 6(e).

135. See supra text accompanying notes 76-82 (discussing the limitations of the subpoena enforcement powers provided to the $9 / 11$ Commission in its enabling statute).

136. See supra text accompanying note 60 .

137. See supra notes 81-82. Such a confrontation would have created "a perfect storm" from a separation of powers perspective, involving all three branches of government in an unprecedented legal confrontation. (With regard to the unprecedented nature of such a potential confrontation, it is worth noting that the Watergate battle for the Nixon White House tapes involved a congressional committee, see Senate Select Comm. on Presidential Campaign Activities v. Nixon, 498 F.2d 725 (D.C. Cir. 1974), and a Department of Justice Special Prosecutor, see United States v. Nixon, 418 U.S. 683 (1974), not an independent investigatory commission housed in the legislative branch such as the $9 / 11$ Commission.) See also infra note 140 (describing a potential "explosive" showdown between the $9 / 11$ Commission and the Bush Administration over access to documents pertaining to $9 / 11$ detainee interrogations).

138. See, e.g., United States v. House of Representatives of the U.S., 556 F. Supp. 150 (D.D.C. 1983) (declining to intervene in a dispute between Congress and the Reagan Administration); Senate Select Comm. on Presidential Campaign Activities, 498 F.2d 725 (concluding that the Senate Committee failed to demonstrate sufficient need to obtain Nixon White House tapes) 
power of Congress to seek a declaratory judgment enforcing its subpoenas to executive branch officials, ${ }^{139}$ the case was settled before the appeals process was complete, and the decision of the district court left many of the most important issues unresolved. ${ }^{140}$

The criminal enforcement process available to the $9 / 11$ Commission $^{141}$ was even less likely to yield a satisfactory resolution of a subpoena dispute with an executive branch agency, as the applicable federal statute ${ }^{142}$ does not clearly require a U.S. Attorney-who is an executive branch official and can be expected to follow the President's directions-to prosecute another executive branch official who is acting at the direction of the President in defying a congressional subpoena. ${ }^{143}$ Thus, in the event of a showdown with the Bush Administration, neither of the enforcement mechanisms available to the 9/11 Commission could be relied upon as tools to compel the executive branch to produce information that the Commission might seek. ${ }^{144}$ An appreciation of the weakness of the legal

139. See Comm. on the Judiciary, U.S. House of Representatives v. Miers, 558 F. Supp. 2d 53, 99 (D.D.C. 2008) (finding that the Bush Administration position that senior White House aides enjoyed absolute immunity from congressional subpoenas was "entirely unsupported by existing case law" and affirming that "Congress has a right-derived from its Article I legislative function-to issue and enforce subpoenas [to executive branch officials] ....").

140. The Miers opinion does not address the merits of the executive privilege claims at issue and does not decide whether the Congress's need for information about the U.S. Attorney firings would outweigh a valid claim of executive privilege. See Miers, 558 F. Supp. $2 d$ at 56 . For additional background on the U.S. Attorney firings that precipitated that case and the constitutional issues at stake, see David M. Driesen, Firing U.S. Attorneys: An Essay, 60 Admin. L. REV. 707 (2008).

141. See Intelligence Authorization Act for Fiscal Year 2003, Pub. L. No. 107-306, § 605(a)(2)(B)(ii), 116 Stat. 2383 (2002).

142. 2 U.S.C. $\$ 194$ (2006).

143. See generally Todd D. Peterson, Prosecuting Executive Branch Officials for Contempt of Congress, 66 N.Y.U. L. REV. 563 (1991). See also supra text accompanying note 82 (discussing the Department of Justice, Office of Legal Counsel, policy of not prosecuting congressional contempt citations brought against executive branch officials who refuse to testify before Congress on the basis of instructions by the President to assert executive privilege). For example, Attorney General Michael Mukasey instructed U.S. Attorney for the District of Columbia Jeffrey Taylor not to present to a grand jury for criminal prosecution the refusals of senior Bush Administration officials Harriet Miers and Joshua Bolten to comply with congressional subpoenas in the U.S. Attorney firings investigation. See generally John W. Dean, Judge Bates Slams the Bush White House's Claims of Congressional Immunity: Why There May Be No Consequences for the White House, Despite the Clear Ruling, FindLAw, Aug. 8, 2008, http://writ.news.findlaw.com/dean/20080808.html (on file with the McGeorge Law Review).

144. An example of an instance in which the $9 / 11$ Commission was unable to obtain information from the Bush Administration is the extensive efforts by the Commission to obtain first access to "war on terror" detainees and then, when that failed, to obtain documents containing information obtained from detainee interrogations. See JANE MAYER, THE DARK SIDE 278-81 (Anchor Books 2009). Mayer described the showdown that almost took place between the 9/11 Commission and the Bush Administration as follows:

The fight over the Commission's access to the detainees built to a head on January 21, 2004. Kean and Hamilton faced off against Tenet, Rumsfeld, and Gonzales in a White House meeting. Tenet and Gonzales "took a very hard line," said [9/11 Commission executive director Philip] Zelikow. They were adamant. Afterward, Zelikow argued for the Commission to defy the CIA and issue a subpoena. "You can imagine how explosive this would have been," said Zelikow. "It would have been a dramatic and very, very difficult confrontation on all sides. But we thought the matter was important enough." The Commission took a vote, but the majority of members opposed getting into 
tools in their arsenal makes it more difficult to criticize Kean and Hamilton for adopting the conciliatory information collection approach that is described above.

So what is the solution to this problem-must national investigative commissions be left largely impotent in their efforts to obtain what may well be the most important information that they are charged with obtaining? Is there no good way to balance the needs of a properly constituted investigative commission against legitimate efforts by executive branch agencies and offices to withhold information that they believe the national interest requires withholding? As always in our constitutional system of divided government, the judicial branch must serve as the final arbiter of such disputes, even if it is reluctant to do so, ${ }^{145}$ and the legislation that created the $9 / 11$ Commission did provide for judicial branch resolution of subpoena disputes. The problem with that legislation, as explained above, is that neither the civil nor the criminal enforcement options available to the $9 / 11$ Commission provided workable solutions. A more effective and less time-consuming subpoena enforcement tool is needed to ensure that national investigative commissions can fulfill their responsibilities.

A possible solution to this problem is to provide national investigative commissions, particularly those like the $9 / 11$ Commission that are investigating a complex matter and are subject to a fixed reporting deadline, with a means of obtaining expedited judicial review and enforcement of their subpoenas. For example, the enabling legislation that creates a commission (or, in the case of commissions created by executive order, such as the Roberts Commission and the Warren Commission, the Joint Resolution of Congress that provides a commission with subpoena power) could provide that civil subpoena enforcement actions shall be heard by a special federal three-judge district court panel, already available under existing law, ${ }^{146}$ and decided on an expedited schedule with direct appeal to the Supreme Court, also already available under existing law, ${ }^{147}$ so as to resolve such disputes as expeditiously as is possible under our legal system. ${ }^{148}$ This approach would be consistent with the national interest

a public confrontation with the CIA.

Id. at 280 .

145. See supra notes $138-40$ and accompanying text.

146. See 28 U.S.C. $\$ 2284$ (2006).

147. See 28 U.S.C. $\$ 1253$ (2006).

148. A similar approach has been proposed to end stalemates between Congress and the executive branch in disputes over enforcement of congressional subpoenas. See EMILY BERMAN, EXECUTIVE PRIVILEGE: A LEGISLATIVE REMEDY (2009), available at http://brennan.3cdn.net/ed3eb0a4b215da3556_fzm6ba8ua.pdf. Berman proposes that Congress adopt a new "Executive Privilege Codification Act" that contains the following provisions:

Sec. 108 Three Judge Panel. "Any civil action brought pursuant to this statute shall be heard and adjudicated by three judges appointed in accordance with 28 U.S.C. $\$ 2284$. Any party may appeal the decision of the panel directly to the Supreme Court in accordance with 28 U.S.C. $\S 1253$."

$\ldots$

Sec. 109 Expedited Schedule. "The federal courts shall place any action filed pursuant to this statute on an expedited schedule and make its timely resolution a priority." 
in prompt resolution of these important disputes and would place responsibility for making the final decision with the appropriate actor in our constitutional system, the Supreme Court.

Such a process would also have several important practical advantages that are particularly well-suited to resolving subpoena disputes involving national investigative commissions. The availability of an expedited judicial enforcement and appeals process makes it less likely that subpoena recipients would try to "run out the clock" on a commission's investigations, particularly if they were asserting legal arguments of dubious merit that would be unlikely to withstand judicial review. This is a significant step forward from the untenable position of the 9/11 Commission, which had no realistic means available to enforce its subpoenas within the time span of its investigation. It also is more consistent with what the public would expect of a national commission investigating a matter of great national importance. It is not likely that the public-or Congress when it created the 9/11 Commission-expected that a commission investigating a national catastrophe would be unable to obtain all the information it needed from the very federal government of which it was a part. Finally, in the event of an intractable dispute between a commission and a government agency, it is appropriate that the Supreme Court should be the final arbiter of what information should be provided to the commission, rather than having the matter decided by an executive branch that may be acting out of political selfpreservation or by a commission that may be overreaching or overzealous in pursuing its investigative mandate.

If an effective subpoena enforcement mechanism is put in place for a commission, then it is possible to avoid the problem that confronted 9/11 CoChairs Kean and Hamilton and to set out some general principles guiding the use of subpoenas by national investigative commissions. First, every commission that is investigating a matter of broad public importance should be granted subpoena power to compel testimony and the production of documents and other evidence. ${ }^{199}$ Second, and most importantly, the commission must be given expedited subpoena enforcement procedures so that subpoenas can be enforced against recalcitrant witnesses within the commission's investigative lifetime. With these procedures available, then the commission should make full use of its

\footnotetext{
Id. at 48-49. Even if one questions whether these provisions tip the balance of power too much toward the Congress in "garden variety" political disputes between a Congress controlled by one party and an executive branch controlled by the other party, for the extraordinary circumstances of a national investigating commission such as those that are the subject of this Article, a strong argument can be made that the balance should be tipped toward disclosure and away from obstruction of the investigation.

149. While this point may appear self-evident, not all commissions are given subpoena powers. For example, the Commission on Wartime Contracting in Iraq and Afghanistan, created by act of Congress in 2008, was not given subpoena powers. See National Defense Authorization Act (NDAA) for Fiscal Year 2009: Commission on Wartime Contracting in Iraq and Afghanistan, Pub. L. No. 110-181, § 841, 122 Stat. 130 (2008). The legislation creating that Commission provides that: "In the event the Commission is unable to obtain testimony or documents needed to conduct its work, the Commission shall notify the committees of Congress of jurisdiction and appropriate investigative authorities." $I d$. $\$ 841$ (e)(2).
} 
subpoena power, and all witnesses and documents should be compelled by subpoena from the outset of the commission's investigation. While these procedures do not guarantee that a commission will always obtain any evidence it may seek, they give a commission the most support and the strongest legal tools that are available under our constitutional system of government.

A final issue relating to subpoena power should be noted and considered carefully. As discussed above, the 9/11 Commission was constructed along partisan lines, with an equal number of Democrat and Republican members. ${ }^{150}$ Although the commission membership was equally divided by party, the issuance of a commission subpoena required either a bipartisan majority of six commissioners or bipartisan agreement of the chair and vice chair. ${ }^{\mid 51}$ The practical effect of this structure was to limit the Commission's subpoena power to subjects where a bipartisan consensus could be forged. ${ }^{152}$ While this requirement of bipartisanship may appear to have a desirable "braking effect" on a commission's ability to subpoena information, it imposes a high cost in terms of the scope and thoroughness of a commission's investigation. Arguably, if a commission has been properly constituted and its investigative authority has been carefully and appropriately defined in its enabling legislation or executive order, then any information within the commission's defined area of investigative jurisdiction should be subject to subpoena by the commission, without regard to whether a bipartisan majority of commission members supports the issuance of a particular subpoena. In addition, it is hard to see why gathering information alone should be perceived as a threat to a commission's operation, particularly if any final commission action regarding the information at issue will require majority support. In other words, in investigations of matters of enormous public importance, more raw information should be better than less. If a commission has more information at its disposal, it will be better informed in developing its conclusions and recommendations and better able to inform the public fully as to the matters it has been charged with investigating.

For all of these reasons, a better approach to commission subpoena power would be to provide for issuance of a subpoena if a specified minimum number of commission members wish to subpoena information (for example, three members of an eight-member commission or four members of a ten-member commission). Such a requirement should be sufficient to ensure that only serious matters of investigative attention would be the subject of subpoenas, while also preventing a "rogue commissioner" or small minority of commissioners from abusing the commission's subpoena power. Most importantly, it would remove altogether the most likely source of contentious partisan divisions from a

150. See supra text accompanying note 68 .

151. National Commission on Terrorist Attacks upon the United States, Pub. L. No. 107-306, $\S 605(\mathrm{a})(2), 116$ Stat. 2410 (2002).

152. See supra note 70 and accompanying text.

153. See id. 
commission's investigative activity. Instead of being influenced by partisan considerations, the focus of subpoena deliberations would be on individual commissioner responsibility and appropriate use of a commission's scarce investigative resources. Finally, providing more liberal authority for issuance of subpoenas should result in greater initial attention to carefully defining a commission's investigative mandate, which is a more appropriate limit on a commission's subpoena power than post hoc reliance on the political affiliation of the commissioners who support issuing a particular subpoena. ${ }^{154}$

If one thinks of the Roberts Commission investigation of the Pearl Harbor attack or the Warren Commission investigation of the Kennedy assassination, rather than the more recent $9 / 11$ Commission investigation, ${ }^{155}$ the merits of a broader commission subpoena power are more readily apparent. Today few would argue that relevant information sought by any three members of the Warren Commission (less than a majority of the seven-member commission) should have been off limits and unavailable to that commission, and most people would agree that more information collection and consideration, rather than less, would have been desirable in investigating the Kennedy assassination. Similarly, in light of the poor performance of the Roberts Commission, discussed above, and the extent to which its investigative work had to be replicated by subsequent investigations, it is difficult to argue that its investigation would have been undermined by allowing any two members of that five-member commission to issue a subpoena. With the benefit of hindsight and the greater analytical detachment that the passage of time provides, it is easier to see that the perceived dangers of a broader independent commission subpoena power are overstated and that a better approach would be to avoid requiring a bipartisan majority to issue investigative subpoenas. $^{156}$

154. This approach would also further appropriate judicial review of commission subpoenas if a subpoena recipient sought to contest a commission subpoena. The reviewing court would simply assess whether the subject matter of the subpoena was within the defined scope of the commission's investigation and rule accordingly, a task that courts routinely perform in all manner of government investigations. Subpoenas that went beyond the scope of the commission's investigative authority would not be enforced by the courts, ensuring that a minority of commissioners could not extend the commission's investigation beyond its defined investigative mandate.

155. The 9/11 Commission may be a particularly poor example to use in considering this issue. The fact that the $9 / 11$ attacks occurred shortly after the most closely contested presidential election contest in modern history and the resulting transfer of executive branch control from one party to another created a particularly divisive political environment in which to conduct an independent, nonpartisan investigation of the attacks. In addition, it is likely that the political divides that surrounded that investigation are still fresh enough to make it difficult to give even the legal issues it presents the kind of dispassionate and nonpartisan analysis that they should receive. For those reasons, the analysis that follows focuses on the Roberts Commission and the Warren Commission, rather than on the $9 / 11$ Commission.

156. Whatever the merits of this argument for more liberal subpoena powers for independent investigative commissions, recent history suggests that Congress, in the present political environment at least, is not likely to embrace it. The Commission on Wartime Contracting in Iraq and Afghanistan, created by act of Congress in 2008, was not given subpoena power. See supra note 149. More recently, in May 2009, Congress created a Financial Crisis Inquiry Commission to investigate "the causes, domestic and global, of the current financial and economic crisis in the United States." See Fraud Enforcement and Recovery Act of 2009, Pub. L. 


\section{E. Witness Testimony-Essential Powers and Procedures}

If there is one lesson that resonates most clearly from the three commission investigations that this Article examines, it is that every effort should be made to create as complete and detailed an investigative record as possible. The Roberts Commission's failure to properly record and document its early witness interviews was later seen as a significant blunder, and the Warren Commission has suffered from all manner of conspiracy and cover-up allegations that have sought to exploit every conceivable flaw and gap in that commission's investigative record. Even the 9/11 Commission, which was well aware of the perceived shortcomings of the Roberts Commission and Warren Commission investigations, ${ }^{157}$ was unable to avoid problems stemming from a failure to adequately document its investigative activities. One example from the 9/11 Commission experience illustrates the problems that can arise in this area.

After the 9/11 Commission report was published, a member of Congress made public allegations that a Department of Defense intelligence officer had told members of the $9 / 11$ Commission staff that one of the most notorious 9/11 hijackers, Mohammed Atta, had been under U.S. government surveillance prior to the $9 / 11$ attacks through a secret Pentagon intelligence program called "Able Danger."158 The staff interview of the intelligence officer had not been transcribed, because, rather than conducting staff questioning of witnesses as formal depositions with a verbatim transcript of the questions and answers, ${ }^{159}$ the

No. 111-21, §5(a), 123 Stat. 1617. That Commission will have ten members, six chosen by the House and Senate Democratic leaders and four chosen by the Republican leaders in Congress; the Democratic leadership will name the chair and the Republican leadership will name the vice chair. See id. $\S 5(\mathrm{~b})(1)$. Most interesting for purposes of the discussion of commission subpoena powers in this Article is the fact that, although the Commission has a majority of members appointed by Democrats, the law requires the assent of at least one Republican member of the Commission to issue a subpoena. See id. The effect of this provision is to require in effect a bipartisan supermajority to issue a subpoena, which is directly contrary to the more liberal subpoena power for independent commissions that this Article advocates. The wisdom of imposing this limitation on the Financial Crisis Inquiry Commission is questionable, as it significantly curtails the scope of the Commission's subpoena power, but it does suggest that even in investigating a matter as important as the global financial crisis, Congress unfortunately appears to be more concerned with partisan gamesmanship than with creating an independent commission that can obtain all of the relevant evidence and facts.

157. See KEAN \& HAMILTON, supra note 3, at 29 (discussing the shortcomings of the Roberts Commission and Warren Commission investigations and observing that " $[\mathrm{t}] \mathrm{he}$ Warren Commission-and the Lockerbie Commission on the bombing of Pan Am Flight 103-had this problem: probably good conclusions, but the reader couldn't tell where they were coming from"). Kean and Hamilton resolved that, "We could not repeat these mistakes. To avoid them, we had to create a new model for how to conduct a high-profile commission." Id.

158. See id. at 114, 294-95, 317; see also SHENON, supra note 53 , at 417 .

159. This was the procedure followed by the Warren Commission, and it is the practice often followed in high-profile congressional investigations, see, for example, Investigation of Whitewater Development Corporation and Related Matters, Depositions Before the Spec. Comm. to Investigate Whitewater Development Corporation and Related Matters, Administered by the Comm. on Banking, Housing, and Urban Affairs, 104th Cong., S. Hrg. 104-869, Vols. XIV-XVIII (1997) (multi-volume collection of staff depositions in the Senate Whitewater investigation), and, of course, it is the normal procedure in both civil litigation depositions and grand jury criminal investigations, in which a court reporter will transcribe the proceedings. 
9/11 Commission practice was to have the responsible staff members prepare a "memorandum for the record" (MFR) after each witness interview. Although a thorough and carefully prepared staff memorandum is certainly a good record of an investigative question and answer session, ${ }^{160}$ it is not an adequate substitute for a verbatim transcript, because it does not capture every word and therefore is subject to dispute after the fact as to its accuracy. This is exactly what happened in the Able Danger situation, where the Defense Department interviewee claimed that something was said in the interview and the 9/11 Commission staff denied that claim. The most that could finally be said about the matter by the commission's chair and vice chair was that "[t]he MFR prepared shortly after the meeting makes no mention of Atta."161 A verbatim transcript of the interview would have made it possible for the 9/11 Commission to "prove a negative" and demonstrate conclusively that the interviewee did not make the disputed statement. This example illustrates both the great value of verbatim transcripts of witness statements and the important point that it is impossible to predict in advance which witness interviews will yield the most important or the most controversial information. ${ }^{162}$

There are other practical reasons why preparing verbatim transcripts of witness statements is advisable. Although it might appear initially that the costs and inconveniences (particularly when classified or highly confidential information is being discussed) outweigh the benefits of preparing verbatim transcripts, and that it is less costly and more efficient to instead rely on staff memoranda for an investigative record-the approach the 9/11 Commission followed-that is not necessarily the case. Enormous amounts of staff time and effort are required to draft complete and scrupulously accurate memoranda of witness interviews. If staff time was an unlimited resource, this would not be a concern, but the reality is that staff investigative time is always a scarce resource for investigative commissions. So the cost of not transcribing witness interviews is actually very high and the result of using a less precise method of documentation, as the Able Danger example discussed above demonstrates, may not satisfy a commission's needs if disputes subsequently arise about what a witness actually said to the commission's staff.

Cost, efficiency, and efficacy for resolving factual disputes are not the only reasons that preparing verbatim transcripts of all witness statements ${ }^{163}$ is the better practice for a national investigation commission to follow. As discussed above, availability of verbatim transcripts of witness interviews can be essential

160. This is the procedure followed by the FBI, which requires agents to prepare a "302" memorandum to document an investigative interview. Whether FBI 302 reports are complete and accurate in all material respects is often an issue in subsequent criminal proceedings.

161. KEAN \& HAMILTON, supra note 3, at 114.

162. See supra notes $24-25$ and accompanying text.

163. The Roberts Commission has been criticized for failing to record the testimony of high-level military witnesses at the outset of its investigation of the Pearl Harbor attacks. See KITTS, supra note 6, at 2425. 


\section{9 / Special National Investigative Commissions}

if issues subsequently arise as to whether or not a witness has knowingly and intentionally provided false information. ${ }^{164} \mathrm{~A}$ uniform practice of administering an oath to all witnesses ${ }^{165}$ is also advisable so as to make it clear that witnesses are under a strict legal obligation to provide complete and accurate testimony. ${ }^{166}$ For all of these reasons, despite the cost and inconvenience of doing so, the best practice is for investigative commissions to swear all witnesses and prepare verbatim transcripts of all witness statements. ${ }^{167}$

An investigative commission also should take precautions to ensure that its ability to obtain accurate and forthcoming testimony from witnesses is not compromised by external influences. As discussed above, ${ }^{168}$ the $9 / 11$ Commission was concerned about government agency "minders" being present at staff interviews of government employees, but it capitulated to the Bush Administration's insistence that agency representatives be allowed to sit in on interviews. This is an area where the 9/11 Commission should not have compromised. ${ }^{169}$ The potential for mischief if government agency "minders" are allowed to "monitor" an employee's interview is obvious to anyone with any knowledge of how government bureaucracies work. ${ }^{170}$ The problem is

164. See supra notes $22-23$ and accompanying text.

165. The Roberts Commission has also been criticized for failing to administer oaths to high-level military witnesses at the outset of its investigation of the Pearl Harbor attacks. See KITTS, supra note 6, at 2425 .

166. Id

167. This is the procedure that the Roberts Commission ultimately followed, after an initial false start taking unsworn and unrecorded statements from senior military officers. See id. It is also the procedure that the Warren Commission followed in most instances. The $9 / 11$ Commission may have faced more obstacles than those commissions in following this approach, because significant portions of its investigation involved classified information. Without minimizing the difficulties presented by dealing with large amounts of classified information, there are ways to address the problem that will not compromise the accuracy and completeness of a commission's investigative record. Stenographers with security clearances can record witness statements. If witness information is too sensitive even to allow a stenographer with a security clearance to participate, then the session (or portions of the session, if the most sensitive issues can be addressed separately) can be taperecorded and the tape-recording maintained under seal by the agency that controls the information. This practice would provide a means of resolving disputes like the "Able Danger" matter described above. It would also be desirable, in the interest of public disclosure and a complete historical record, to provide some mechanism for subsequent declassification review and eventual public release of all or most such commission records. This is similar to the procedures that Congress eventually adopted for dealing with the Kennedy assassination records, see President John F. Kennedy Assassination Records Collection Act of 1992, Pub. L. No. 102-526, 106 Stat. 3443 (1993), and the Nixon White House tape recordings, see Presidential Recordings and Materials Preservation Act of 1974, Pub. L. 93-526, 88 Stat. 1695 (1976). While such procedures might be overkill in a routine government investigation, for special investigative commissions pursuing matters as important as Pearl Harbor, the Kennedy assassination, and the $9 / 11$ attacks, it is a mistake to shortchange history by adopting less rigorous measures on grounds of cost and convenience.

168. See supra notes 86-89 and accompanying text.

169. Cf. Commission Memo, supra note 88 (referencing an internal "Commission Sensitive" 9/11 Commission staff memorandum reporting that "minders have positioned themselves physically and conducted themselves in a manner that we believe intimidates witnesses from giving full and candid responses to our questions").

170. The same concerns are present with witnesses from the private sector, but the problem is particularly acute in investigations focusing on the performance of government agencies, such as the three 
compounded when a major purpose of an investigation is to determine whether government agencies performed properly and whether there are management or policy problems within government that need to be addressed. It is simply unrealistic to believe that government agency employees will be forthright and candid in assessing the performance and possible shortcomings of the agency that employs them when they know that their statements will be reported back to their superiors at the agency. Future national investigative commissions should pay greater heed to the practical realities of investigative fact-finding and adopt procedures that will ensure as accurate and complete an investigative record as possible.

For the same reason, national investigative commissions investigating major historical events like Pearl Harbor, the Kennedy assassination, and the 9/11 attacks should be given the power to grant testimonial immunity to witnesses. The Warren Commission had immunity power ${ }^{171}$ but did not use it. The 9/11 Commission did not have immunity power, but witness immunity issues did not arise during its investigation. More recently, concerns about granting immunity to witnesses have been a major point of contention in congressional consideration of the creation of some kind of commission to investigate the treatment of detainees and other actions of the Bush Administration subsequent to the $9 / 11$ terrorist attacks. ${ }^{172}$

An in-depth analysis of the immunity issue is beyond the scope of this Article, but one central point merits emphasis-immunity power is often essential if an investigation is to discover the truth. This is the reason that immunity is routinely used in criminal investigations, and in many cases immunizing lower-level participants is the only way to obtain the true facts about criminal activity and hold responsible those who directed the activity. ${ }^{173}$ If it is appropriate to grant immunity in routine criminal prosecutions, allowing admitted criminals to escape punishment in return for providing essential information and testimony to prosecute others, the same tool should be available in an investigation into matters of enormous public importance such as those that are the subject of the commissions discussed in this Article. Two examples from recent history illustrate this point. Few today would argue that it was a mistake for the Senate Watergate Committee to grant John Dean immunity, because society would have been better served by punishing Dean more harshly rather than having him share his dramatic story of Nixon White House misdeeds with a

independent commission investigations that are the focus of this Article.

171. See Herman, supra note 39 , at 1644 n.69.

172. See, e.g., Jack M. Balkin, Op-Ed., A Body of Inquiries, N.Y. TIMES, Jan. 11, 2009, at WK11, available at http://www.nytimes.com/2009/01/11/opinion/1 lbalkin.html (arguing that "American commissions and hearings should have the power to bestow immunity to compel testimony").

173. Cf. BEN-VENISTE, supra note 26, at 7 (describing John Dean's efforts to obtain immunity in the Watergate investigation and observing that the "criminal justice system is dependent on this process" of plea bargaining and granting immunity from prosecution for cooperation and testimony). 
congressional committee and a riveted nation of television viewers. ${ }^{174}$ It is admittedly a closer case, but most would agree that the country was better served by having Oliver North and John Poindexter testify under immunity about the Reagan Administration's Iran-Contra misconduct, ${ }^{175}$ even though that televised congressional testimony ultimately caused their criminal convictions to be reversed and allowed them to escape punishment for the crimes they committed. ${ }^{176}$

These examples illustrate the principle that in some instances the public's need to know can outweigh the interests of the criminal justice system in prosecuting particular individuals for their criminal actions. ${ }^{177}$ As with

174. Dean did not escape prosecution entirely, because the Watergate Special Prosecutions Task Force found a way to prosecute him for a matter that was not covered in his immunized Senate Testimony. See id. at 13.

175. One reason the case is closer is that while subsequent events proved that John Dean was truthful in his Senate Watergate testimony, see, e.g., id. at 23 ("Everything that John Dean had testified to under oath before the Senate Watergate Committee, and more, was irrefutably corroborated by the tape-recorded words of the conspirators themselves."), there is reason to believe that North and Poindexter were less than truthful in their immunized testimony and probably shaded the truth to protect their superiors. $C f$. LAWRENCE E. WALSH, FINAL REPORT OF THE INDEPENDENT COUNSEL FOR IRAN/CONTRA MATTERS, PART XI: CONCLUDING OBSERVATIONS, Aug. 4, 1993, available at http://www.fas.org/irp/offdocs/walsh/part_xi.htm ("Congress gave immunity to North and Poindexter, who incriminated only themselves and who largely exculpated those responsible for the initiation, supervision and support of their activities.").

176. See generally United States v. Poindexter, 951 F.2d 369 (D.C. Cir. 1991), cert. denied 506 U.S. 1021 (1992); United States v. North, 910 F.2d 843 (D.C. Cir. 1990); United States v. North, 920 F.2d 940 (D.C. Cir. 1990), cert. denied 500 U.S. 941 (1991). But cf. WALSH, supra note 175.

The disrespect for Congress by a popular and powerful President and his appointees was obscured when Congress accepted the tendered concept of a runaway conspiracy of subordinate officers and avoided the unpleasant confrontation with a powerful President and his Cabinet. In haste to display and conclude its investigation of this unwelcome issue, Congress destroyed the most effective lines of inquiry by giving immunity to Oliver L. North and John M. Poindexter so that they could exculpate and eliminate the need for the testimony of President Reagan and Vice President Bush.

Immunity is ordinarily given by a prosecutor to a witness who will incriminate someone more important than himself. Congress gave immunity to North and Poindexter, who only incriminated themselves and who largely exculpated those responsible for the initiation, supervision and support of their activities. This delayed and infinitely complicated the effort to prosecute North and Poindexter, and it largely destroyed the likelihood that their prompt conviction and appropriate sentence would induce meaningful cooperation.

Id.

177. Even the federal prosecutor who arguably suffered the greatest interference from immunity grants, Iran-Contra Independent Counsel Lawrence Walsh, has acknowledged that in cases of great public importance-and the independent commission investigations that are the subject of this Article undoubtedly are such cases-the public's right to know and Congress's need for information in order to legislate must prevail over the more narrow interests of the criminal justice system:

[T]he competing roles of Congress and the Executive (here represented by Independent Counsel) must be borne in mind. As Independent Counsel recognized from the outset of his investigation, it is Congress (in the case of the Iran/contra affair, its Select Committees) that is primarily responsible for the accurate public disclosure of the facts concerning transactions such as the Iran/contra matters. Ultimately, it is Congress that is empowered to legislate in a manner that not only will preclude future similar transactions in a narrow sense, but that also will facilitate the effective management of foreign policy and that will discourage disregard for existing legal strictures.

Although the Independent Counsel also has a reporting function, his first responsibility, in contrast, 
consideration of the issue of appropriate subpoena power for a national investigative commission, ${ }^{178}$ consideration of the immunity issue is probably best examined, not in the context of a controversial and politically charged current commission proposal, such as the proposed "truth commission" investigation of the Bush Administration, but in the context of a commission that benefits from the clearer view of hindsight and subsequent experience, such as the Warren Commission investigation of the Kennedy assassination. The damage to the reputation of our national government and the tremendous public resources that have been expended ${ }^{179}$ as a result of the failure of the Warren Commission's investigation to satisfy the public's concerns about the Kennedy assassination illuminates the benefit of hindsight for consideration of the immunity issue. If the facts of that investigation had been different and definitive answers could have been obtained by granting immunity to a few individuals, doing so clearly would have been in the national interest. ${ }^{180}$ Future commissions investigating matters of great national importance should have the power to use every tool that our legal system provides in finding the truth about the matters they are charged with investigating, and immunity is perhaps the single most powerful truth-compelling tool in our legal arsenal.

\section{F. Transparency and Public Access}

The final recommendations for independent investigative commission policies and procedures will be unsurprising in light of the arguments advanced above. History shows that secrecy and lack of transparency are perhaps the greatest long-term threats to a commission investigation. Future commissions should avoid following procedures that may later enable critics to charge a "cover-up" or a failure to vigorously pursue all appropriate and reasonable lines of investigative inquiry. ${ }^{181}$ For that reason the operating policies and procedures

is the prosecution of criminal conduct. Accordingly, it is not primarily his duty to develop for the public a knowledge of what occurred.

When a conflict between the oversight and prosecutorial roles develops-as plainly occurred in the Iran/contra affair-the law is clear that it is Congress that must prevail. This is no more than a recognition of the high political importance of Congress's responsibility. It also is the appropriate place to strike the balance, as resolution of this conflict calls for the exercise of a seasoned political judgment that must take a broad view of the national interest.

Lawrence E. Walsh, Final Report of the Independent Counsel for Iran/Contra Matters, Part X: Political Oversight and The Rule of LAw, Aug. 4, 1993, available at http:/www.fas.org/irp/offdocs/ walsh/part_x.htm.

178. See supra note 155 and accompanying text.

179. See supra note 35 and accompanying text (discussing subsequent efforts to examine the findings and conclusions of the Warren Commission).

180. Cf. LaWrence E. Walsh, Final Report of the IndePEndent Counsel for Iran/Contra MATTERS, PART XI: CONCluding OBSERVATIONS, Aug. 4, 1993, available at http://www.fas.org/irp/offdocs /walsh/part_xi.htm (quoting views of Iran-Contra Independent Counsel Lawrence Walsh).

181. The Warren Commission example alone is sufficient to demonstrate the validity of this assertion. See KEAN \& HAMILTON, supra note 3, at 25 ("For decades, the Warren Commission's findings have been poked 
of a national investigative commission should tilt strongly toward openness and transparency whenever and however possible. In general, commission hearings should be open to the public and the testimony of all significant witness should be presented in open public hearings. ${ }^{182}$ If there are legitimate reasons why particular testimony cannot be made public, such as testimony involving classified information, then provision should be made for closed sessions, but there should be procedures in place to provide for eventual public release of the information. ${ }^{183}$ To further facilitate eventual public disclosure of commission activities and an accurate historical record, minutes of nonpublic commission meetings should be prepared and either made public with the commission's final report or made subject to procedures facilitating their eventual public release. ${ }^{184}$ The end result of these policies and procedures should be a commission factfinding and deliberation process that is open to contemporaneous public examination and that will create the most accurate and complete historical record possible.

and prodded by conspiracy theorists.").

182. Cf. id. at 29 "We could not repeat these mistakes [of the Warren Commission and the Roberts Commission]. To avoid them we had to create a new model for how to conduct a high-profile commission. We would be nonpartisan and independent. We would be public instead of secretive." (emphasis added)). Notwithstanding Kean and Hamilton's after-the-fact embrace of a public approach to the 9/11 Commission's work, another Commissioner has described how narrowly the Commission avoided what he characterized as "a near-death experience" of adopting a closed hearing approach, voting by only a 6-4 margin (with Hamilton in the minority favoring closed hearings) to hold open hearings. See BEN-VENISTE, supra note 26, at 219-20. BenVeniste speculates that perhaps Lee Hamilton's "bad experience with Colonel Oliver North in the Iran-Contra hearings over which he presided as chairman of the House Intelligence Committee-where North's mediasavvy performance seemed to wrest control of the hearings from his congressional interrogators - had a scarring effect on Lee." Id.

183. See KITTS, supra note 6, at 24-25.

184. See id. One of the members of the $9 / 11$ Commission has subsequently provided a candid and enlightening account of the differing views of the members of that commission on the issue of how to treat the minutes of commission meetings:

I pushed early and continuously throughout the life of the commission for the most vigorous and independent examination of the facts and circumstances leading up to $9 / 11$. I had no quarrel with those who were more interested in policy considerations and recommendations. But $I$ felt those recommendations would have to flow from a robust and credible investigation of the facts in order to be accepted by Congress and the public. And I believed we should operate in as open a manner as possible. I was therefore taken aback by the proposal voiced by our chairman at the February [2003] meeting that the minutes of our meetings reflect only decisions made by the commission and not include the comments of individual commissioners or record the way we might vote individually on issues before us. Eventually, after a few meetings, I was to prevail in my repeated requests for more "fulsome" minutes that reflected what we talked about and how we voted. And, when we were finishing our final report, I proposed that we include the minutes of our meetings in an appendix to the report. My proposal was soundly rejected; the minutes were not to be publicly available until July 2009 , five years from when we issued our final report.

BEN-VENISTE, supra note 26, at 214. 


\section{CONCLUSION}

These recommendations are based on one guiding principle: when investigating matters of enormous national importance, every possible effort should be made to conduct the investigation in a manner which will ensure that all relevant facts are discovered and made public. Although the special circumstances of particular future investigative commissions may require departures from some of these recommendations, past experience suggests that future commissions should be extremely wary of adopting any procedure that might later call into question the independence, thoroughness, and good faith of their investigation. 